\title{
A Crystal-chemical Framework for Relaxor versus Normal Ferroelectric Behavior in Tetragonal Tungsten Bronzes
}

\author{
X. Zhu ${ }^{1}$, M. Fu ${ }^{2}$, M. C. Stennett ${ }^{3}$ P. M. Vilarinho ${ }^{4}$, I. Levin ${ }^{5}$, C.A. Randall ${ }^{6}$ \\ J. Gardner ${ }^{7}$, F.D. Morrison, ${ }^{7}$ and I. M. Reaney ${ }^{3}$ \\ ${ }^{1}$ Department of Materials Science and Engineering, \\ Zhejiang University, Hangzhou, China. \\ ${ }^{2}$ Shanxi Materials Analysis and Research Center, \\ School of Materials Science and Engineering, \\ Northwestern Polytechnical University, \\ Xi'an 710000 , China. \\ ${ }^{3}$ Department of Materials Science and Engineering \\ University of Sheffield, Sheffield, S1 3JD, UK \\ ${ }^{4}$ Department of Materials and Ceramics Engineering \\ CICECO, Aveiro Materials Institute \\ University of Aveiro, 3810-193 Aveiro, Pt. \\ ${ }^{5}$ Materials Measurement Science Division, \\ National Institute of Standards and Technology, \\ Gaithersburg MD 20899, USA \\ ${ }^{6}$ Center for Dielectrics and Piezoelectrics \\ Materials Research Institute, Millennium Science Complex \\ The Pennsylvania State University, University Park, PA 16802, USA \\ ${ }^{7}$ School of Chemistry, University of St Andrews, \\ St Andrews, KY16 9ST, UK.
}




\begin{abstract}
Tetragonal Tungsten Bronzes (TTBs) - an important class of oxides known to exhibit ferroelectricity - undergo complex distortions, including rotations of oxygen octahedra, which give rise to either incommensurately or commensurately modulated superstructures. Many TTBs display broad, frequency-dependent relaxor dielectric behaviour rather than sharper frequency-independent normal ferroelectric anomalies but the exact reasons that favor a particular type of dielectric response for a given composition remain unclear. In this contribution the influence of incommensurate/commensurate displacive modulations on the onset of relaxor/ferroelectric behaviour in TTBs is assessed in the context of basic crystal-chemical factors, such as positional disorder, ionic radii and polarizabilities, and point defects. We present a predictive crystal-chemical model that rationalizes composition-structure-properties relations for a broad range of TTB systems.
\end{abstract}




\section{1) Introduction}

Since Magneli ${ }^{1}$ first reported tetragonal tungsten bronzes (TTBs), many complex oxides crystallizing with this structure have been shown to exhibit ferroelectricity with TTBs hosting the broadest variety of chemistries after perovskite-structured materials. TTBs consist of

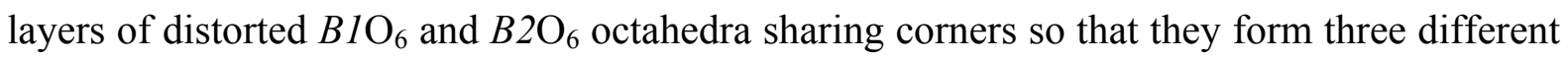
interstices: pentagonal $(A 2)$; square ( $A 1$, sometimes referred to as the perovskite site) and trigonal (C) which may be occupied by cations according to a general formula $(A 2)_{4}(A 1)_{2}(C)_{4}(B 1)_{2}(B 2)_{8} \mathrm{O}_{30}$, Figure $1 .^{2}$ For so-called 'stuffed' TTBs, such as $\mathrm{K}_{6} \mathrm{Li}_{4} \mathrm{Nb}_{10} \mathrm{O}_{30}$ $(\mathrm{KLN}), \mathrm{Li}$ is found in the trigonal $\mathrm{C}$ site $^{3}$ but in 'filled' TTBs the trigonal interstice $C$ is empty and the general formula reverts to $(A 2)_{4}(A 1)_{2}(B 1)_{2}(B 2)_{8} \mathrm{O}_{30}$, e.g. $\mathrm{Ba}_{4} \mathrm{Na}_{2} \mathrm{Nb}_{10} \mathrm{O}_{30}$ $(\mathrm{BNN})^{3}$ For 'unfilled' TTBs, such as $\mathrm{Sr}_{\mathrm{x}} \mathrm{Ba}_{1-\mathrm{x}} \mathrm{Nb}_{2} \mathrm{O}_{6}$, some of the $A 1 / A 2$ sites remain vacant. ${ }^{4}$

Several studies have attempted to classify TTBs using a geometric tolerance-factor $(t)$ approach similar to that defined for perovskites by Goldschmidt ${ }^{5}$. Wakiya et al. ${ }^{6}$ suggested individual tolerance factors for $A 2$ and $A 1$ sites:

$$
\begin{gathered}
t_{A 2}=\frac{\left(R_{A 2}+R_{O}\right)}{\sqrt{23-12 \sqrt{3}\left(R_{B}+R_{O}\right)}} ; \\
t_{A 1}=\frac{\left(R_{A 1}+R_{O}\right)}{\sqrt{2}\left(R_{B}+R_{O}\right)}
\end{gathered}
$$

that combine to give an effective tolerance factor $\left(t_{\mathrm{TTB}}\right)$ for the entire structure:

$$
t_{T T B}=\frac{\left(t_{A 1}+2 t_{A 2}\right)}{3}
$$

where $R_{A 1}, R_{A 2}, R_{B}$ and $R_{\mathrm{O}}$ are the ionic radii of the $A 1, A 2, B$ and $\mathrm{O}$ ions, respectively. $t_{T T B}$, provides a metric to define whether the TTB structure is likely to occur for a given set of ions. Here, $t_{\mathrm{A} 1}$ is the same as that proposed by Goldschmidt for perovskites.

Unfilled TTB structured ceramics based on compounds $\mathrm{MNb}_{2} \mathrm{O}_{6}(\mathrm{M}=\mathrm{Ba}, \mathrm{Sr}, \mathrm{Pb})$ have been extensively studied since the 1950s and have been shown to exhibit a range of dielectric properties and phase transition temperatures. ${ }^{7-14}$ TTB-structured compositions in $\mathrm{Pb}_{1-\mathrm{x}} \mathrm{Ba}_{\mathrm{x}} \mathrm{Nb}_{2} \mathrm{O}_{6}$ solid solutions are normal ferroelectrics ${ }^{7-12}$, whereas the response of $\mathrm{Sr}_{1-\mathrm{x}} \mathrm{Ba}_{\mathrm{x}} \mathrm{Nb}_{2} \mathrm{O}_{6}$ changes from normal ferroelectric to relaxor-like at $x \approx 0.5$. $^{4,13,15}$ Despite diverse ferroelectric and dielectric behavior, all compositions in this family exhibit weak incommensurate superstructure reflections at $h+{ }^{1} / 4-\delta, k+{ }^{1} / 4-\delta, l+{ }^{1} / 2$ positions arising from frustrated octahedral tilting. ${ }^{12-14}$ Filled TTBs, such as $\mathrm{Ba}_{4} \mathrm{Na}_{2} \mathrm{Nb}_{10} \mathrm{O}_{30}$, have also been shown 
to exhibit ferroelectricity concomitant with an incommensurate superstructure similar to that in unfilled stoichiometries. ${ }^{13,15,16}$

In 2003, a family of filled TTB structured ceramics were reported based on $\mathrm{Ba}_{4} \mathrm{RE}_{2} \mathrm{Ti}_{4} \mathrm{Nb}_{6} \mathrm{O}_{30}(\mathrm{RE}=\text { rare earth })^{17-20}$ which built on earlier work by Ikeda et al. ${ }^{21}$ $\mathrm{Ba}_{4} \mathrm{RE}_{2} \mathrm{Ti}_{4} \mathrm{Nb}_{6} \mathrm{O}_{30}$ ceramics with $\mathrm{RE}$ ionic radius $>1.3 \AA$ (pseudo 12-fold coordination number $(\mathrm{CN}=12))$ exhibit incommensurate superstructure reflections at positions $h+{ }^{1} / 4-\delta$, $k+{ }^{1} / 4-\delta, l+{ }^{1} / 2{ }^{19,20}$ like the $\mathrm{MNb}_{2} \mathrm{O}_{6}$-based compositions, but for $\mathrm{RE}$ radii $<1.3 \AA$, there is a non-lock-in phase transition from an incommensurate to commensurate (Ima2) supercell with $a \approx \sqrt{ } 2 a_{T T B}, b \approx \sqrt{ } 2 a_{T T B}$ and $c \approx 2 c_{T T B}$, Figure $2 \mathrm{a}, \mathrm{b} .{ }^{19,20}$ The incommensurately modulated compositions $(\mathrm{RE}=\mathrm{La}, \mathrm{Bi})$ are relaxors whereas commensurately modulated ones $(\mathrm{RE}=\mathrm{Nd}$, $\mathrm{Sm}, \mathrm{Gd})$ are ferroelectric at room temperature and their Curie temperature $\left(\mathrm{T}_{\mathrm{C}}\right)$ increases with decreasing ionic radius. ${ }^{20}$ Levin and co-workers ${ }^{19}$ concluded that relaxor behaviour in this family of TTBs is coupled directly to the incommensurate modulation whereas ferroelectricity is induced by the transition to commensurate octahedral tilting, stable for RE having ionic radii $<1.3 \AA^{19}{ }^{19}$ This model not only explained the coupling of relaxor/ferroelectric behavior to the appearance of incommensurate/commensurate superstructure but also gave a plausible rationale for the increase in $T_{C}$ with decreasing $R E$ ionic radius, i.e. the restructuring (tilting) of the octahedral framework is driven by the $A 1$ tolerance factor in a manner reminiscent of perovskites.

Relaxor-to-ferroelectric transitions have also been observed by the authors of refs [22-26] in Sr-based TTB compounds such as $\mathrm{Sr}_{4} \mathrm{RE}_{2} \mathrm{Ti}_{4} \mathrm{Nb}_{6} \mathrm{O}_{30}$ and $\mathrm{Sr}_{5} \mathrm{RETi}_{3} \mathrm{Nb}_{7} \mathrm{O}_{30}(\mathrm{RE}=\mathrm{La}, \mathrm{Nd}$, $\mathrm{Sm}$, and $\mathrm{Eu}$ ). These authors did not investigate the coupling of relaxor/ferroelectric behavior to incommensurate/commensurate modulations but did note that the onset of ferroelectric behavior at room temperature occurred at lower RE (A1) ionic radii than for Ba-based TTB compositions. They concluded that the $A 2-A 1$ ionic-radius difference is another important factor in determining dielectric characteristics. ${ }^{22-24}$

In this contribution, we present new transmission electron microscopy (TEM) data on $\mathrm{Sr}_{5} \mathrm{RETi}_{3} \mathrm{Nb}_{7} \mathrm{O}_{30}(\mathrm{RE}=\mathrm{La}$ and $\mathrm{Sm}), \mathrm{Ba}_{4} \mathrm{RE}_{0.67}{ }_{1.33} \mathrm{Nb}_{10} \mathrm{O}_{30}, \mathrm{RE}=\mathrm{La}, \mathrm{Nd}, \mathrm{Sm}, \mathrm{Gd}, \mathrm{Dy}, \mathrm{Y}$ and $\mathrm{Ba}_{4} \mathrm{RE}_{2} \mathrm{Nb}_{5} \mathrm{Ti}_{5} \mathrm{O}_{29.5} 0.05 \quad(\mathrm{RE}=\mathrm{La}$ and $\mathrm{Nd})$, to confirm the role of incommensurate/commensurate modulations in deciding relaxor versus ferroelectric behavior. The results are then compared to previous studies on compounds such as $\mathrm{MNb}_{2} \mathrm{O}_{6}(\mathrm{M}=\mathrm{Ba}$, $\mathrm{Sr}, \mathrm{Pb}$ ), $\mathrm{Ba}_{4} \mathrm{Na}_{2} \mathrm{Nb}_{10} \mathrm{O}_{30}$ and $\mathrm{K}_{4} \mathrm{RE}_{2} \mathrm{Nb}_{10} \mathrm{O}_{30}$ in order to develop a universal model that 
explains/predicts the primary dielectric response in a wide range of TTB structured ceramics. Specifically, we will establish the relative importance of the incommensurate/commensurate transition in relaxor/ferroelectric behaviour in the context of conventional crystal-chemical concepts, such as positional disorder, ionic radius, polarisability, and point defects.

\section{Experimental procedure}

Fabrication and electrical characterization of all samples have been reported previously and the reader is asked to refer to appropriate references in the text for each compositional set. New data however, has been generated for some of the compositions using TEM. Samples for TEM were prepared from sintered pellets by either sectioning and grinding to a thickness of $<30 \mu \mathrm{m}$ followed by ion milling until perforation using a Gatan ${ }^{1}$ Precision Ion Polishing System (PIPS-Model 691, Pleasanton, USA, operated at $4 \mathrm{kV}$ with an incidence angle $4^{\circ}$ and $8^{\circ}$ ) or by crushing and dispersing the powder on lacey carbon-coated copper grids. Samples were examined in a Hitachi H9000 microscope (Tokyo, Japan) operated at $300 \mathrm{kV}$, a JEOL 2200FS HR-TEM (Tokyo, Japan) operated at $200 \mathrm{kV}$ and an FEI Titan (300 kV). Kinematic electron diffraction patterns were simulated using the CARINE 3.1 software. For reflection indexes and lattice parameters, the subscript TTB refers to the aristotype structure with $P 4 / m b m$ symmetry.

\section{3) Results and discussion}

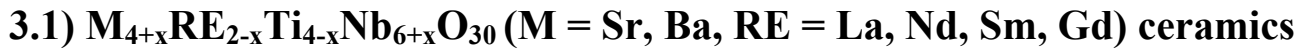

Figure 3 shows the relative permittivity as a function of temperature $(100 \mathrm{~Hz}$ to $1 \mathrm{MHz})$ and the polarization-electric field hysteresis loops at room temperature for $\operatorname{Sr}_{5} \mathrm{RETi}_{3} \mathrm{Nb}_{7} \mathrm{O}_{30}$ $(\mathrm{RE}=\mathrm{La}$ or $\mathrm{Sm})$. For $\mathrm{Sr}_{5} \mathrm{LaTi}_{3} \mathrm{Nb}_{7} \mathrm{O}_{30}$ (Figure $\left.3 \mathrm{a}\right)$, the relative permittivity shows relaxor type behavior with a distinct shift of the maximum of relative permittivity to higher temperatures and an associated increase in the magnitude and temperature of the loss peak. ${ }^{25,26}$ The relative permittivity of $\mathrm{Sr}_{5} \mathrm{SmTi}_{3} \mathrm{Nb}_{7} \mathrm{O}_{30}$ displays a frequency independent maximum on heating, indicating a normal ferroelectric phase transition. However, this peak still exhibits frequency dispersion at lower temperatures (Fig. 3). The authors' previous work. ${ }^{25,26}$ revealed the recovery of the ferroelectric phase in $\mathrm{Sr}_{5} \mathrm{SmTi}_{3} \mathrm{Nb}_{7} \mathrm{O}_{30}$ by aging at a temperature below the transition for several hours. For $\mathrm{Sr}_{5} \mathrm{LaTi}_{3} \mathrm{Nb}_{7} \mathrm{O}_{30}$, a slim nonlinear

\footnotetext{
1 The identification of any commercial productor trade name does not imply endorsement or recommendation by the National Institute of Standards and Technology.
} 
hysteresis loop (Figure 3c) was observed at room temperature $\left(\sim 25{ }^{\circ} \mathrm{C}\right)$, behavior characteristic of a relaxor whereas $\mathrm{Sr}_{5} \mathrm{SmTi}_{3} \mathrm{Nb}_{7} \mathrm{O}_{30}$ (Figure 3d) is a normal ferroelectric.

Figure 4 shows the typical experimental and simulated selected-area zone-axis electron diffraction patterns (ZADP) obtained along the $[001]_{T T B},[110]_{T T B}$ and $[100]_{T T B}$ directions. For $\mathrm{Sr}_{5} \mathrm{LaTi}_{3} \mathrm{Nb}_{7} \mathrm{O}_{30}$, superlattice reflections are observed at $h / 2, k / 2,0$ in $[001]_{\text {TTB }}$ ZADPs (Figure 4a) along with weak splitting/streaking in the $\langle 110\rangle_{T T B}$ directions. For $\mathrm{Sr}_{5} \mathrm{LaTi}_{3} \mathrm{Nb}_{7} \mathrm{O}_{30}$, superlattice reflections are also observed in the [110] $]_{\text {TTB }}$ ZADP (Figure 4b) at locations $h / 4+\delta, k / 4+\delta), l / 2$, where $\delta \approx 0.12$, along with diffuse streaks parallel to $\left\langle 110>_{T T B}\right.$, the direction of weak reflection splitting in the $[001]_{\text {ттв }}$ patterns. Simulations of the diffraction patterns for the incommensurate $\mathrm{Sr}_{5} \mathrm{LaTi}_{3} \mathrm{Nb}_{7} \mathrm{O}_{30}$ structure were carried out using a commensurate approximant based on ionic positions reported by Labbe et $a{ }^{27} a \approx$ $2 \sqrt{2} a_{T T B}, \quad b \approx \sqrt{2} a_{T T B}$, and $c \approx 2 c_{T T B}$ with $B b m 2$ symmetry, and the patterns are indexed accordingly.

For $\mathrm{Sr}_{5} \mathrm{SmTi}_{3} \mathrm{Nb}_{7} \mathrm{O}_{30}$, the $[001]_{T T B}$ ZADP exhibited commensurate superlattice reflections at $h / 2, k / 2,0$ positions but no splitting was observed, while in the $[110]_{\text {TTB }}$ patterns commensurate superlattice reflections appear at $h / 2, k / 2, l / 2$ positions (Figure $4 c$ ) Simulations of $\mathrm{Sr}_{5} \mathrm{SmTi}_{3} \mathrm{Nb}_{7} \mathrm{O}_{30}$ were performed using a unit cell with Ima2 symmetry $a \approx \sqrt{2} a_{T T B}, b \approx$ $\sqrt{2} a_{T T B}$, and $c \approx 2 c_{T T B}$ after Levin et al. ${ }^{19}$ and Stennett et al. ${ }^{20}$ and the patterns in Figure 4 are indexed accordingly. The diffraction patterns from $\mathrm{Sr}$ based TTBs are similar to those published by Levin et al. ${ }^{19}$ and Stennett et al. ${ }^{20}$ (Figure 5) for Ba based compositions. The latter authors reported relaxor behaviour for $\mathrm{RE}=\mathrm{La}$ and $\mathrm{Bi}$ but normal ferroelectric behaviour for $\mathrm{RE}=\mathrm{Nd}, \mathrm{Sm}$ and $\mathrm{Gd}$. Moreover, Levin and co-workers ${ }^{19}$ demonstrated that the paraelectric-ferroelectric transition as a function of temperature in $\mathrm{Ba}_{4} \mathrm{Nd}_{2} \mathrm{Ti}_{4} \mathrm{Nb}_{6} \mathrm{O}_{30}$ was associated with a transformation from incommensurate to commensurate distorted octahedral network, Figure 6.

An HRTEM image for $\mathrm{Sr}_{5} \mathrm{LaTi}_{3} \mathrm{Nb}_{7} \mathrm{O}_{30}$ with [001] $]_{T T B}$ zone axis is shown in Figure 7. The grain is composed of a mosaic of planar defects with distinct boundaries between different regions. Fourier Transform (FT) images confirm splitting of the incommensurate reflections in region $\mathrm{A}$ along $[110]_{\text {TTB }}$ and $\mathrm{B}$ along $[1-10]_{\text {TTB }}$. For $\mathrm{Sr}_{4} \mathrm{La}_{2} \mathrm{Ti}_{4} \mathrm{Nb}_{6} \mathrm{O}_{30}$ similar splitting and orientation of the incommensurate superstructure reflections were also observed. This composition did not, however, exhibit the mosaic of defects observed for $\mathrm{Sr}_{5} \mathrm{LaTi}_{3} \mathrm{Nb}_{7} \mathrm{O}_{30}$ but instead showed an assembly of domains having differently oriented 
modulation directions., Figure 8. Figure 9 is a dark field TEM image of $\mathrm{Sr}_{5} \mathrm{SmT}_{\mathrm{i} 3} \mathrm{Nb}_{7} \mathrm{O}_{30}$ recorded near the $[110]_{T T B}$ zone axis using a $h / 2, k / 2, l / 2$ commensurate superlattice reflection, which reveals the presence of planar defects similar to those reported as long-range ferroelectric domains in Ba based compositions by Stennett et al. ${ }^{20}$

The results presented above confirm that $\mathrm{Sr}_{5} \mathrm{RETi}_{3} \mathrm{Nb}_{7} \mathrm{O}_{30}$ and $\mathrm{Sr}_{4} \mathrm{RE}_{2} \mathrm{Ti}_{4} \mathrm{Nb}_{6} \mathrm{O}_{30}$ exhibit similar structural and dielectric behavior to $\mathrm{Ba}_{4} \mathrm{RE}_{2} \mathrm{Ti}_{4} \mathrm{Nb}_{6} \mathrm{O}_{3}$ ceramics. Direct coupling of the relaxor to incommensurate and normal ferroelectric to commensurate behavior is thus confirmed and $\mathrm{Sr}_{5} \mathrm{RETi}_{3} \mathrm{Nb}_{7} \mathrm{O}_{30}$ compositions follow the same trends as those described by Levin et al. ${ }^{19}$ and Stennett ${ }^{20}$ and coworkers. The aging behavior of $\mathrm{Sr}_{5} \mathrm{SmTi}_{3} \mathrm{Nb}_{7} \mathrm{O}_{30}$ suggests that this composition is transitional between a stable relaxor/incommensurate and ferroelectric/commensurate state. The presence of only commensurate superstructure in TEM samples of $\mathrm{Sr}_{5} \mathrm{SmTi}_{3} \mathrm{Nb}_{7} \mathrm{O}_{30}$ suggests that preparation of the thin foil may have stabilized the commensurate, ferroelectric phase over the relaxor, incommensurate structure.

This contribution deals explicitly with niobates since they dominate the landscape of ferroelectric/relaxor TTB research. However, tantalates have also been studied, albeit to a lesser degree, and in general show lower $\mathrm{T}_{\mathrm{C}}$-values due to the lower polarisability of the $\mathrm{Ta}^{5+}$ in comparison to the $\mathrm{Nb}^{5+}$ ion. ${ }^{28,29}$

\section{2) $\mathrm{Ba}_{4} \mathrm{RE}_{0.67}{ }_{1.33} \mathrm{Nb}_{10} \mathrm{O}_{30}(\mathrm{RE}=\mathrm{La}, \mathrm{Nd}, \mathrm{Sm}, \mathrm{Gd}, \mathrm{Y})$, the role of A1-site vacancies}

Figure 10 shows the relative permittivity versus temperature plots for $\mathrm{Ba}_{4} \mathrm{RE}_{0.67}{ }_{1.33} \mathrm{Nb}_{10} \mathrm{O}_{30}(\mathrm{RE}=\mathrm{La}, \mathrm{Nd}, \mathrm{Sm}, \mathrm{Gd}, \mathrm{Y})$ ceramics, originally described by Gardner and Morrison ${ }^{30}$, which illustrate that compositions with RE ion size $\leq 1.27 \AA(\mathrm{Nd})$ show ferroelectric behavior consistent with the observations of Levin et al. ${ }^{19}$ and Stennett et al. ${ }^{20}$ whereas those with $\mathrm{La}(1.32 \AA)$ exhibit a relaxation at low temperature. However, on examination of the relevant electron diffraction patterns (Figure 11), $\mathrm{Ba}_{4} \mathrm{La}_{0.67}{ }_{1.33} \mathrm{Nb}_{10} \mathrm{O}_{30}$ has a commensurate superstructure consistent with the cell proposed by Labbe et al. ${ }^{27}(\mathrm{Bbm} 2$, $a \approx 2 \sqrt{ } 2 a_{T T B}, \quad b \approx \sqrt{ } 2 a_{T T B}$ and $\left.c \approx 2 c_{T T B}\right), \mathrm{Ba}_{4} \mathrm{Nd}_{0.67}{ }_{1.33} \mathrm{Nb}_{10} \mathrm{O}_{30}$ is incommensurate, but $\mathrm{Ba}_{4} \mathrm{Sm}_{0.67}{ }_{1.33} \mathrm{Nb}_{10} \mathrm{O}_{30}$ is commensurate with $a \approx \sqrt{ } 2 a_{T T B}, b \approx 3 \sqrt{2} a_{T T B}$ and $c \approx 2 c_{T T B}$, although some grains were incommensurate presumably due to a heterogeneous distribution of the RE ion. The effect of $A 1$ site cation vacancies is clearly highly complex with a unique ' $3 \sqrt{ } 2 a_{T T B}$ ' superstructure of BS N hitherto unobserved in TTB compounds. The data hints at 'lock-in' incommensurate behavior not previously reported for TTBs and further work is required to 
understand the role of $A 1$ site vacancies. Likely, the $A 1$ vacancies permit a relaxation of the frustrated tilt network that gives rise to the incommensurate modulation, allowing predominately commensurate modulations throughout the series.

\section{3) $\mathrm{Ba}_{4} \mathrm{RE}_{2} \mathrm{Nb}_{5} \mathrm{Ti}_{5} \mathrm{O}_{29.5} \quad 0.05(\mathrm{RE}=\mathrm{La}$ and $\mathrm{Nd})$, the role of $\mathrm{O}$ vacancies}

Additional work is required to understand the role of cation vacancies in TTB-structured ceramics but the influence of O-vacancies $\left(V_{O} \ddot{*}\right)$ on the incommensurate/commensurate modulation is comparatively clear. Figure 12 shows the $<110>$ ZADP and dielectric constant and loss vs. temperature data for $\mathrm{Ba}_{4} \mathrm{RE}_{2} \mathrm{Ti}_{5} \mathrm{Nb}_{5} \mathrm{O}_{29} \quad(\mathrm{RE}=\mathrm{La}$, $\mathrm{Nd}$ ) in comparison with $\mathrm{Ba}_{4} \mathrm{Nd}_{2} \mathrm{Ti}_{4} \mathrm{Nb}_{6} \mathrm{O}_{30}$. The deficit of $\mathrm{B}$-site positive charge in $\mathrm{Ba}_{4} \mathrm{RE}_{2} \mathrm{Ti}_{5} \mathrm{Nb}_{5} \mathrm{O}_{29}$ is compensated by oxygen vacancies $\left(V_{O}{ }^{*}\right)$. For $\mathrm{Ba}_{4} \mathrm{La}_{2} \mathrm{Ti}_{5} \mathrm{Nb}_{5} \mathrm{O}_{29}$, relaxor behavior is anticipated based on the ionic radius of La, as discussed in section 3.1 and consistent with $\mathrm{Ba}_{4} \mathrm{La}_{2} \mathrm{Ti}_{4} \mathrm{Nb}_{6} \mathrm{O}_{30}$. However, $\mathrm{Ba}_{4} \mathrm{Nd}_{2} \mathrm{Ti}_{5} \mathrm{Nb}_{5} \mathrm{O}_{29}$ is a relaxor rather than a normal ferroelectric and differs primarily with $\mathrm{Ba}_{4} \mathrm{Nd}_{2} \mathrm{Ti}_{4} \mathrm{Nb}_{6} \mathrm{O}_{30}$ in that the former composition has all positions filled within the oxygen sublattice. To explain the difference in behavior, it is important to view the incommensurate to commensurate transition as essentially a change in tilt configuration of the oxygen sublattice, Figure 2, and as such it is strongly influenced by oxygen stoichiometry. In perovskites, octahedral tilt transitions are readily suppressed by acceptor doping. Tkach et al. ${ }^{31}$ studied the effect of acceptor doping on the low temperature $\mathrm{Pm} 3 m-I 4 / \mathrm{mcm}$ tilt transition in $\mathrm{SrTiO}_{3}$ by substituting $\mathrm{Mg}^{2+}$ for $\mathrm{Ti}^{4+}$ $\left(\mathrm{Mg}_{\mathrm{Ti}}{ }^{\prime \prime} \equiv V_{O} \cdot \ddot{)}\right)$ and argued that $V_{O} \cdot{ }^{\prime \prime}$ disrupt the long-range cooperative 'cogwheel-like' rotation of the oxygen $\left[\mathrm{O}_{6}\right]$ octahedra, effectively suppressing the improper ferroelastic transition temperature. In TTBs, $V_{O}{ }^{*}$ suppress the transition from an incommensurate to a commensurate tilt system in a similar manner to that reported by Tkach et al. ${ }^{31}$ for $\mathrm{SrTiO}_{3}$ and thereby decrease or suppress the coupled ferroelectric $T_{C}$. If the $\mathrm{Nb} / \mathrm{Ti}$ ratio is increased from 5:5 to $6: 4$, the concentration of $V_{O}{ }^{*}$ decreases and long-range commensurate tilting/ferroelectric order dominates, an effect elegantly shown by the authors of ref [32]. 


\section{4) $\mathrm{MNb}_{2} \mathrm{O}_{6}$ TTB ceramics}

Although the end members have proven difficult to fabricate, compositions in the $\mathrm{Sr}_{1-\mathrm{x}} \mathrm{Ba}_{\mathrm{x}} \mathrm{Nb}_{2} \mathrm{O}_{6}$, solid solution have Curie temperatures ranging from $333 \mathrm{~K}$ to $473 \mathrm{~K}$ for $0.25 \leq \mathrm{x} \leq 0.75 ., 13,15$ with a cross over from relaxor to normal ferroelectric behavior at $\mathrm{x}>0.5$, Figure 13. ${ }^{33}$ Superstructure reflections in $\mathrm{Sr}_{1-\mathrm{x}} \mathrm{Ba}_{\mathrm{x}} \mathrm{Nb}_{2} \mathrm{O}_{6}$ were first reported by Revkevich et $a l .{ }^{34}$ and their incommensurate character was determined by Schneck et al. ${ }^{15}$ with incommensurate reflections appearing along both $\langle 110\rangle$ directions of the tetragonal cell at $\pm(h+[1+\delta] / 4, k+[1+\delta] / 4, l / 2)$, where $\delta=0.26$. The influence of temperature and composition on the incommensurate superstructure in $\mathrm{Sr}_{1-\mathrm{x}} \mathrm{Ba}_{\mathrm{x}} \mathrm{Nb}_{2} \mathrm{O}_{6}$ were studied comprehensively by Bursill and $\mathrm{Lin}^{13}$ who noted that when the $\mathrm{Ba}$ content varies from 0.25 to 0.75 in $\mathrm{Sr}_{1-\mathrm{x}} \mathrm{Ba}_{\mathrm{x}} \mathrm{Nb}_{2} \mathrm{O}_{6}$, the value of $\delta$ is virtually constant. Bursill and $\mathrm{Lin}^{13}$ attributed the origin of the incommensurate superstructure to the existence of two competing hypothetical orthorhombic commensurate phases having virtually identical energies with unit cells with $a$ $\approx \sqrt{ } 2 a_{T T B}, b \approx 2 \sqrt{ } 2 a_{T T B}, c \approx 2 c_{T T B}$ and $a \approx \sqrt{ } 2 a_{T T B}, b \approx \sqrt{ } 2 a_{T T B}, c \approx 2 c_{T T B}$. Essentially however, for the purpose of this contribution, it is sufficient to note that SBN compositions exhibit incommensurate superstructure accompanied by normal ferroelectric behavior for $x>0.5$ and relaxor for $x<0.5 .^{33}$

$\mathrm{Pb}_{1-\mathrm{x}} \mathrm{Ba}_{\mathrm{x}} \mathrm{Nb}_{2} \mathrm{O}_{6}$ compositions transform from the prototype 4/mmm to either ferroelectric orthorhombic $m m 2$ or tetragonal $4 m m$ symmetry with $\mathrm{T}_{\mathrm{C}}$ for $\mathrm{PbNb}_{2} \mathrm{O}_{6}$ at $823 \mathrm{~K}$ and extrapolated to $\sim 693 \mathrm{~K}$ for $\mathrm{BaNb}_{2} \mathrm{O}_{6}$, Figure 14. ${ }^{7-12} \mathrm{~Pb}_{1-\mathrm{x}} \mathrm{Ba}_{\mathrm{x}} \mathrm{Nb}_{2} \mathrm{O}_{6}$ composition are incommensurate, as illustrated by the $\langle 110\rangle_{T T B}$ ZADP pattern shown in the inset of Figure $15 \mathrm{a}^{12}$ and exhibit discommensurate superstructure domains, Figure 15a, in addition to conventional $90^{\circ}$ and $180^{\circ}$ domains, Figure $15 \mathrm{~b} .{ }^{12}$ The incommensurate superstructure in $\mathrm{Pb}_{1-\mathrm{x}} \mathrm{Ba}_{\mathrm{x}} \mathrm{Nb}_{2} \mathrm{O}_{6}$ is reported to exist above $\mathrm{T}_{\mathrm{C}}{ }^{12}$ in a manner similar to that described by Levin and co-workers. ${ }^{19}$ Single crystal dielectric data also show that relaxor characteristics may be obtained perpendicular to the polar axis, which implies that frustration arising from the incommensurate modulation still plays a role in normal ferroelectric TTBs. ${ }^{35}$ More dielectric measurements are required in single crystals from other TTB systems to establish whether this phenomenon disappears at the same time as the incommensurate modulation. 


\section{4) Crystal-chemical Framework}

Table 1 summarises the data presented in section 3 and also includes other TTB-structured compounds discussed in the scientific literature. Table 2 lists the ionic polarizability and radii for the pertinent ions in the TTB structure. These data are adopted from Shannon and Prewitt $^{36}$ and Shannon ${ }^{37}$, respectively. Starred radii are extrapolated from lower coordination numbers. The polarisability values of $\mathrm{Nb}^{5+}$ with respect to $\mathrm{Ta}^{5+}$ are controversial with most authors suggesting that their magnitudes should be reversed based on empirical comparisons of isostructural niobates and tantalates such as $\mathrm{BaZn}_{1 / 3} \mathrm{Nb}_{2 / 3} \mathrm{O}_{3}\left(\varepsilon_{r}=36\right)$ and $\mathrm{BaZn}_{1 / 3} \mathrm{Ta}_{2 / 3} \mathrm{O}_{3}$ $\left(\varepsilon_{r}=29\right) .{ }^{29}$ Table 3 lists the primary dielectric behavior of the TTB compounds $(R=$ Relaxor, $F=$ Ferroelectric) along with the $A l$ tolerance factor, the average $A$-site ionic radii $((A 1+A 2) / 2)$ and, when available, the corresponding $O-B-O$ bond lengths. The reader is referred to Table 1 for references.

From Table 1 and Table 3, it is evident that the onset of normal ferroelectric rather than relaxor behavior is dominated by two critical crystal-chemical factors: the presence of the Ima 2 commensurate as opposed to incommensurate superstructure and a B-site with a single $d^{0}$ species $\left(\mathrm{Nb}^{5+}\right)$ provided $A 1$ and $A 2$ sites contain ion(s) that have a relatively large average radius, $R_{A v}=\left(R_{A 1}+R_{A 2}\right) / 2$.

The effect of lone-pair ions on $T_{C}$ in TTBs is evident but surprisingly small. Comparison of $T_{C}$ for $\mathrm{BaTiO}_{3}(398 \mathrm{~K})$ and $\mathrm{PbTiO}_{3}(768 \mathrm{~K})^{38}$ with those of $\mathrm{PbNb}_{2} \mathrm{O}_{6}(835 \mathrm{~K})$ and $\mathrm{BaNb}_{2} \mathrm{O}_{6}$ (projected, $693 \mathrm{~K})^{12}$ reveals that coupling of the lone-pair ion (A-site) to the $d^{0}$ ion (B-site) in TTBs is considerably weaker relative to perovskites. This effect can be attributed to the more rigid structure of the TTB octahedral framework in comparison to perovskites which inhibits $A 1-B$ coupling through the oxygen ligand; vacancies in $A 1 / A 2$ sites of the unfilled $\mathrm{MNb}_{2} \mathrm{O}_{6}$ family can also weaken this coupling. The relatively small effect of the A-site lone pair ion is best exemplified by $\mathrm{Ba}_{4} \mathrm{Bi}_{2} \mathrm{Ti}_{4} \mathrm{Nb}_{6} \mathrm{O}_{30}$ which remains relaxor despite the large polarisability of the Bi species. ${ }^{20}$ In this instance, the critical crystal-chemical factors favoring relaxor over ferroelectric behaviour are the disordered $B$-cations (i.e. $\mathrm{Nb}$ and $\mathrm{Ti}$ ) and the incommensurate modulation. Substitution of Bi by the considerably less polarizable Nd ion (see Table 2) forces the structure to become commensurate and induces long-range $B$-site displacements, despite $\mathrm{Ti}^{4+} / \mathrm{Nb}^{5+}$ short-range order/disorder. ${ }^{20}$ 
The transition from ferroelectric to relaxor in the incommensurately modified $\mathrm{Sr}_{1-\mathrm{x}} \mathrm{Ba}_{\mathrm{x}} \mathrm{Nb}_{2} \mathrm{O}_{6}$ system hints at a latent ion size effect similar to that in $\mathrm{Ba}_{\mathrm{x}} \mathrm{Sr}_{1-\mathrm{x}} \mathrm{TiO}_{3}$ solid solutions. ${ }^{38}$ In $\mathrm{BaTiO}_{3}$, the large $\mathrm{Ba}$ ion stretches the O-Ti-O bond length and enhances polarisability, shifting the onset of ferroelectricity above ambient temperature. ${ }^{38}$ As the $\mathrm{Sr}$ concentration increases, the O-Ti-O bond length shrinks, decreasing the effective polarisability of $\mathrm{Ti}^{4+}$, and the transition becomes sub-ambient. A similar 'rattling ion' argument can be used for $\mathrm{Sr}_{1-\mathrm{x}} \mathrm{Ba}_{\mathrm{x}} \mathrm{Nb}_{2} \mathrm{O}_{6}$. For higher $\mathrm{Ba}$ concentrations the polarisability of the $\mathrm{Nb}$-ion is enhanced and long range ferroelectric order occurs. At high Sr concentrations $(\mathrm{x}>0.5)$, the $\mathrm{O}-\mathrm{Nb}-\mathrm{O}$ bond length shortens, the length scale of polar order recedes and relaxor behaviour ensues.

$\left(\mathrm{Ba}_{\mathrm{x}} \mathrm{Sr}_{1-\mathrm{x}}\right)_{4} \mathrm{Na}_{2} \mathrm{Nb}_{10} \mathrm{O}_{30}$ compositions also illustrate the B-site stretching effect which contributes to the driving force for ferroelectricity with the $T_{C}$ increasing from $518 \mathrm{~K}$ to 833 $\mathrm{K}^{16,39,40}$ as $\mathrm{Ba}$ concentration increases. $T_{C}$ reported for $\mathrm{Ba}_{4} \mathrm{Na}_{2} \mathrm{Nb}_{10} \mathrm{O}_{30}$ is similar to that of $\mathrm{Pb}_{1-\mathrm{x}} \mathrm{Ba}_{\mathrm{x}} \mathrm{Nb}_{2} \mathrm{O}_{6}$ despite the absence of the lone-pair effect. Shannon ${ }^{37}$ quotes the polarisability of $\mathrm{Na}^{+}\left(1.8 \AA^{3}\right)$ as considerably lower than that of $\mathrm{Pb}^{2+}\left(6.58 \AA^{3}\right)$ and it is difficult to explain such a strong effect of $\mathrm{Na}$ on the $A 1$ sites. However, comparison with perovskites illustrates that $\mathrm{Na}^{+}$on the $A$ - and $\mathrm{Nb}^{5+}$ on the $B$-site couple strongly with multiple phase transitions as temperature increases. ${ }^{41}$ Although $\mathrm{Ba}_{4} \mathrm{Na}_{2} \mathrm{Nb}_{10} \mathrm{O}_{30}$ is incommensurate, as discussed in detail by the authors of ref $16, \mathrm{Sr}_{4} \mathrm{Na}_{2} \mathrm{Nb}_{10} \mathrm{O}_{30}$ is commensurate with an $\operatorname{Im} 2 a$ symmetry $(a \approx$ $2 \sqrt{ } 2 a_{T T B}, b \approx 2 \sqrt{ } 2 a_{T T B}$ and $\left.c \approx 2 c_{T T B}\right) .{ }^{40}$ This tendency towards a commensurate supercell as $\mathrm{Sr}$ concentration increases (O-B-O bond length shrinks) can explain why $\mathrm{Sr}_{4} \mathrm{Na}_{2} \mathrm{Nb}_{10} \mathrm{O}_{30}$ is ferroelectric rather than relaxor, consistent with the generic behavior of TTB structured compounds.

The role of point defects in relaxor versus ferroelectric behavior in TTBs is complex and in need of further study, particularly for cation vacancies since there are multiple interstices, each of which accommodates ions of different size. Generally speaking, vacancies should add to the degree of disorder and promote relaxor behavior, however it is their subtle effect on the incommensurate/commensurate modulation that is most pertinent to this contribution. For $\mathrm{BL} \mathrm{N}$, vacant square sites appear to relax the frustrated tilt system and produce a long range commensurate modulation with the Labbe et al. unit cell $\left(B b m 2, a \approx 2 \sqrt{2} a_{T T B}, b \approx \sqrt{ } 2 a_{T T B}\right.$ and 
$\left.c \approx 2 c_{T T B}\right)^{27}$, which along with a competing cell $\left(a \approx \sqrt{ } 2 a_{T T B}, b \approx \sqrt{ } 2 a_{T T B}\right.$ and $\left.c \approx 2 c_{T T B}\right)$, was proposed by Bursill and $\operatorname{Lin}^{13}$ to explain the incommensurate modulations in $\operatorname{Sr}_{1-\mathrm{x}} \mathrm{Ba}_{\mathrm{x}} \mathrm{Nb}_{2} \mathrm{O}_{6}$. $\mathrm{Ba}_{4} \mathrm{Nd}_{0.67} \quad{ }_{1.33} \mathrm{Nb}_{10} \mathrm{O}_{30}$ in contrast is incommensurate and ferroelectric much like $\mathrm{Ba}_{5} \mathrm{Nb}_{10} \mathrm{O}_{30}$. Many grains in $\mathrm{Ba}_{4} \mathrm{Sm}_{0.67}{ }_{1.33} \mathrm{Nb}_{10} \mathrm{O}_{30}$ exhibit an hitherto unreported unit cell with lattice parameters $a \approx \sqrt{ } 2 a_{T T B}, b \approx 3 \sqrt{ } 2 a_{T T B}$ and $c \approx 2 c_{T T B}$, which suggests lock-in type commensurate behavior intermediate between the $a \approx 2 \sqrt{ } 2 a_{T T B}, b \approx \sqrt{ } 2 a_{T T B}$ and $c \approx 2 c_{T T B}$ and $a \approx \sqrt{ } 2 a_{T T B}, b \approx$ $\sqrt{ } 2 a_{T T B}, c \approx 2 c_{\text {TTB }}$ cells in a manner proposed but not observed in $\mathrm{Sr}_{1-\mathrm{x}} \mathrm{Ba}_{\mathrm{x}} \mathrm{Nb}_{2} \mathrm{O}_{6}$ by Bursill and Lin. ${ }^{13}$ However, considerably more work is required to expand our knowledge of BRE $\mathrm{N}$ series as a function of composition and temperature before the phase transitions of this unusual class of TTBs can be definitively explained. We note however, that $\mathrm{Ba}_{4} \mathrm{RE}_{0.67}{ }_{1.33} \mathrm{Nb}_{10} \mathrm{O}_{30}$ compositions, first reported by Wakiya et al. ${ }^{6}$, have higher concentration of vacancies in the $A 1 / A 2$ sites than the unfilled TTBs and in this contribution we refer to them as 'empty'. They are closer in composition to $\mathrm{Sr}_{1-\mathrm{x}} \mathrm{Ba}_{\mathrm{x}} \mathrm{Nb}_{2} \mathrm{O}_{6}$ than $\mathrm{Ba}_{4} \mathrm{Nd}_{2} \mathrm{Ti}_{4} \mathrm{Nb}_{6} \mathrm{O}_{30}$ and perhaps it is therefore not surprising that they exhibit hybrid behavior between these two classes of TTBs.

The data presented in Figure 12 indicates that $V_{O}{ }^{*}$ suppress the incommensurate-commensurate transition in TTBs (section 3.3). This observation is predictable based on our accepted understanding of the role of $V_{O} \ddot{ }$ on the onset of octahedral tilt transitions. Intuitively, the frustrated TTB incommensurate tilt system may relax and become more stable as the $V_{O}{ }^{*}$ relieve local strain at the octahedral apices. Moreover, the transition to a long range ferroelectric Ima2 cell becomes more difficult as the required co-operative cogwheel rotations of the oxygen octahedra are inhibited. However, extensive atomistic simulations and modeling work are required to confirm this mechanism.

In many systems, either electron diffraction has not been carried out or the refinements ignored the commensurate/incommensurate tilting modulations. However, in light of this contribution, the relaxor to ferroelectric transition in, e.g. the $\mathrm{Ba}_{4} \mathrm{RE}_{2} \mathrm{Fe}_{2} \mathrm{Nb}_{8} \mathrm{O}_{30}(\mathrm{RE}=\mathrm{Pr}$, $\mathrm{Nd}, \mathrm{Sm}, \mathrm{Eu}$ ) compositions as a function of decreasing RE ion size reported by Josse and co-workers $^{42,43}$, is likely coupled to some extent to an incommensurate/commensurate transition, as described by Levin and co-workers ${ }^{19}$ but issues may arise in interpreting the 
behavior of these samples due to the variable valence of Fe which may introduce $\mathrm{V}_{\mathrm{O}}{ }^{\circ}$ and locally disrupt long range coupling of O-octahedral rotations.

Zhu et $\mathrm{al}^{23-26}$ have suggested that a large $A 1-A 2$ ionic size difference is important for inducing ferroelectricity. According to our framework, this should be particularly true for compositions with a single $d^{0}$ B-site species having high ionic polarisability such as $\mathrm{Nb}^{5+}$. The class of TTB structured compounds which best fits this description, the alkali RE niobates $\left(\mathrm{K}_{4} \mathrm{RE}_{2} \mathrm{Nb}_{10} \mathrm{O}_{30}, \mathrm{Re}=\mathrm{La}, \mathrm{Nd}, \mathrm{Sm}, \mathrm{Gd}, \mathrm{Dy}\right)$, is perhaps the least known. ${ }^{44}$ Scott et $a l .{ }^{44}$, as illustrated in their plot of $c_{0}$ spacing versus $T_{C}$ (Figure 16), report dielectric anomalies above RT for RE radii $<1.36 \AA$, that exhibit dielectric hysteresis but these authors do not present comprehensive data illustrating Curie-Weiss behavior nor polarization-field hysteresis loops. Curie-Weiss behavior was reported for $\mathrm{K}_{4} \mathrm{La}_{2} \mathrm{Nb}_{10} \mathrm{O}_{30}$ which has a low temperature transition with no dielectric hysteresis, typical of relaxor rather than normal ferroelectric behaviour. ${ }^{44}$ The data presented by Scott et al. ${ }^{44}$ may be re-interpreted with $\mathrm{K}_{4} \mathrm{RE}_{2} \mathrm{Nb}_{10} \mathrm{O}_{30}$ compositions likely undergoing a transition from incommensurate to commensurate as RE ionic radius decreases, which induces a ferroelectric transition, as discussed by Levin and co-workers. ${ }^{19}$ Interestingly, $\mathrm{K}_{4} \mathrm{Bi}_{2} \mathrm{Nb}_{10} \mathrm{O}_{30}$ is reported to have a ferroelectric transition at $160{ }^{\circ} \mathrm{C}^{45}$ in contrast to $\mathrm{Ba}_{4} \mathrm{Bi}_{2} \mathrm{Ti}_{4} \mathrm{Nb}_{6} \mathrm{O}_{30}$ which remains relaxor, as reported by Stennett et al. ${ }^{20}$ The ionic radius of $\mathrm{Bi}^{3+}$ in pseudo $\mathrm{CN}=12$ is $\approx 1.36 \AA$, similar to $\mathrm{La}^{3+}$ and therefore $\mathrm{K}_{4} \mathrm{Bi}_{2} \mathrm{Nb}_{10} \mathrm{O}_{30}$ is probably incommensurate despite being ferroelectric. ${ }^{45}$ The onset of a ferroelectric instability above room temperature for $\mathrm{K}_{4} \mathrm{Bi}_{2} \mathrm{Nb}_{10} \mathrm{O}_{30}$ (and not $\mathrm{Ba}_{4} \mathrm{Bi}_{2} \mathrm{Ti}_{4} \mathrm{Nb}_{6} \mathrm{O}_{30}{ }^{20}$ which is relaxor) is most likely because of the absence of disorder on the $\mathrm{B}$-site and the slightly larger ion-size of $\mathrm{K}$ with respect to Ba. Recently, the authors of ref 46 have suggested that even antiferroelectric (AFE) behaviour may be present for $\mathrm{K}_{4} \mathrm{Gd}_{2} \mathrm{Nb}_{10} \mathrm{O}_{30}$. AFE behavior has never been previously been reported in a TTB and the antiparallel dipole alignment may not necessarily be compatible with the distortions of the octahedral sublattice. Further electron diffraction studies as a function of temperature are therefore required.

Figure 17 is a plot of the average, $(A 1+A 2) / 2$ ionic radius versus the $A 1$ tolerance factor (perovskite sites) for the TTB compounds in Table 3. This plot unifies the behavior of a 
wide range of TTB stoichiometries and compositions. The average $(A 1+A 2) / 2$ ionic radius is a metric which influences the $\mathrm{O}-\mathrm{B}-\mathrm{O}$ bond length similar to the effect of $\mathrm{Ba} / \mathrm{Sr}$ ratio in $\mathrm{BST}$ perovskite-structured ceramics. ${ }^{38}$ The $A 1$ tolerance factor is related to the driving force for octahedral tilting in a manner similar to that described for $\mathrm{Ba}$ - and Sr-based complex perovskites by Reaney et $a l .{ }^{47}$ Low $A 1$ tolerance factors generally occur for compositions with small A1 site ions which also decrease the average $(A 1+A 2) / 2$ ionic radius. Hence, these two metrics are co-dependent but each relates to a different crystal-chemical mechanism for stabilizing ferroelectricity. Two trend lines that are drawn on the plot refer to $(\mathrm{Ba}+\mathrm{K})$-based and $(\mathrm{Pb}+\mathrm{Sr})$-based TTBs. The trend lines reflect the close similarity in ionic radius between $\mathrm{Ba}(1.61 \AA)$ and $\mathrm{K}(1.64 \AA)$ and $\mathrm{Pb}(1.49 \AA)$ and $\mathrm{Sr}(1.44 \AA)$ in twelve-fold coordination, Table $2 .^{36,37}$

Here, we assumed that unfilled sites have the same effective cation radius as the equivalent filled sites due to the rigid octahedral framework. Ubic et al ${ }^{48}$ discussed in detail the effective ionic radius of A-site vacancies in perovskite-structured ceramics where the octahedral framework is more compliant. They concluded that cation vacancies had a comparatively small effect on the lattice parameter. In addition, no attempt is made to calculate average $A 1$ tolerance factors using $A 1$ average site occupancies. This latter simplification is in part based on lack of detailed knowledge in many cases of the occupancies because of the absence of reliable structural refinements. Additionally, existing evidence suggests that the smallest-size $A l$ species dominate the driving force for tilting rather than the average size since $\mathrm{Sr}_{5} \mathrm{SmTi}_{3} \mathrm{Nb}_{7} \mathrm{O}_{30}$ and $\mathrm{Sr}_{4} \mathrm{Sm}_{2} \mathrm{Ti}_{4} \mathrm{Nb}_{6} \mathrm{O}_{30}$ are both ferroelectric even though their $A 1$ site occupancy must be different based on their formulae. ${ }^{23,24}$ The ionic radii for $A 2$-site ions (CN15) have been extrapolated from $\mathrm{CN} 10$ and CN12 data.

Figure 17 illustrates the competing crystal-chemical factors for the onset of normal ferroelectric behavior in the TTB family. Large average $(A 1+A 2) / 2$ ionic radii stretch the $\mathrm{O}-\mathrm{B}-\mathrm{O}$ bond length, enhance polarisability and promote long range ferroelectric coupling. Concurrently, a low $A 1$ tolerance factor drives the transition from incommensurate to commensurate which is also associated with normal ferroelectric behavior. In between these two competing driving forces, relaxor behavior dominates. The relaxor regime for Ba- and 
$\mathrm{K}$-based TTBs is more narrow than that of Sr based TTBs which have smaller $A 1$ ionic radii. This reflects the true crystal-chemical origin of the $A 2-A 1$ size difference trend proposed by Zhu et al. ${ }^{23-24}$ and predicts that the vast majority of $\mathrm{Cs}(C N 15=2 \AA)$ and $\mathrm{Rb}(C N 15=1.85 \AA)$ based niobate TTBs, if stable, should be ferroelectric based on the large potential $A 2$ ionic radius which forces $(A 1+A 2) / 2$ to be large even for small $A 1$ site species. The two driving forces for ferroelectricity would therefore potentially overlap with either an extremely narrow or no intermediate region of relaxor behaviour. It is interesting to note that TTBs often exhibit lower temperature relaxations in addition to the primary ferroelectric or relaxor transition. One such case is presented in Figure 3 for $\mathrm{Sr}_{5} \mathrm{SmTi}_{3} \mathrm{Nb}_{7} \mathrm{O}_{30}$. In the context of this contribution, we note only that the complex interaction of multiple crystallographic sites with the incommensurate/commensurate modulation coupled to site disorder is likely to lead to so called 're-entrant' relaxor behavior, a topic dealt with by Zhu et al (2014). ${ }^{54}$ However, the primary dielectric behavior discussed in this contribution is dominated by the average A-site ionic radius and the A1 tolerance factor, as illustrated in Figure 17.

\section{Conclusions}

1) A generic model for TTB structured ceramics is presented which assesses the role of the incommensurate/commensurate modulation in the context of more conventional crystallographic factors.

2) The most critical factors stabilizing ferroelectric over relaxor behavior are the appearance of the Ima2 commensurate supercell reported by Levin et al. ${ }^{19}$ and Stennett et $a l^{20}$ and the presence of a single $d^{0}$ species on the B-site. In the latter case it is important that the average $(A 1+A 2) / 2$ site ion is sufficiently large to enhance the polarisability of $\mathrm{Nb}^{5+}$ in a manner similar to $\mathrm{Ti}^{4+}$ in $\mathrm{BST}$ perovskites.

3) Lone-pair ions play a much lesser role in the onset of ferroelectric behaviour compared with perovskites, possibly because $A-B$ coupling through $\mathrm{O}$ is restricted because of the more rigid octahedral framework in TTBs.

4) Vacancies play an important role in controlling the nature of the incommensurate/commensurate modulation. O-vacancies suppress the onset of the 
commensurate tilt system (Ima2) and promote incommensurate/relaxor behavior. More work is required to understand the role of cation vacancies.

5) The trends in $T_{C} / T_{M}$ for $\mathrm{K}_{4} \mathrm{RE}_{2} \mathrm{Nb}_{10} \mathrm{O}_{30}{ }^{43}$ and $\mathrm{Ba}_{4} \mathrm{RE}_{2} \mathrm{Fe}_{2} \mathrm{Nb}_{8} \mathrm{O}_{30}{ }^{42}$ as a function of decreasing RE ion size can now be explained by considering the onset of a incommensurate/commensurate transition of the type described by Levin et al. ${ }^{19}$ and Stennett et al. ${ }^{20}$

6) A plot of $(A 1+A 2) / 2)$ versus $\mathrm{t}_{A 1}$ illustrates succinctly the competing driving forces for the onset of normal ferroelectric versus relaxor behaviour in TTB-structured ceramics. This plot can be used to guide synthesis of new TTB compositions with desired properties.

\section{References:}

1. A. Magneli, The Crystal Structure of Tetragonal Potassium Tungsten Bronze, Arki Kemi 1, 213-221 (1949).

2. S. C. Abrahams, P. B. Jamieson, J. L. Bernstein, Ferroelectric Tungsten Bronze-Type Crystal Structures. III. Potassium Lithium Niobate $\mathrm{K}_{6-\mathrm{x}-\mathrm{y}} \mathrm{Li}_{4+\mathrm{x}} \mathrm{Nb}_{10+\mathrm{y}} \mathrm{O}_{30}$, J. Chem. Phys, 54(6), 2355-2364 (1971).

3. L.G Van Uitert, H.J. Levinstein, J.J. Rubin, C.D. Capio, E.F. Dearborn, W.A. Bonner, Some Characteristics of Niobates having "Filled" Tetragonal Tungsten Bronze-like Structures, Mater. Res. Bull., 3(1), 47-57 (1968)

4. A. M. Glass, Investigation of Electrical Properties of $\mathrm{Sr}_{1-\mathrm{x}} \mathrm{Ba}_{\mathrm{x}} \mathrm{Nb}_{2} \mathrm{O}_{6}$ with Special Reference to Pyroelectric Detection, J. Appl. Phys., 40 4699-4713 (1969).

5. V.M. Goldschmidt, Geochemische Verteilungsgesetze der Elemente. Skrifter Norske Videnskaps-Akad. Oslo, (I) Mat. Natur., (1926).

6. K. Masuno, X-ray and dielectric studies of the systems $\left(\mathrm{Ba}_{1-\mathrm{X}} \mathrm{R}_{2 \mathrm{x} / 3}\right) \mathrm{Nb}_{2} \mathrm{O}_{6}$, where $\mathrm{R}$ is $\mathrm{Y}$, Sm or La, J. Phys. Soc. Jpn, 19, 323 (1964)

7. G. Goodman, Ferroelectric Properties of Lead Metaniobate, J. Am. Ceram. Soc., 36, 368-372 (1953).

8. R. Lane, D. L. Mack and K. R. Brown, Dielectric, Piezoelectric and Pyroelectric Properties of the $\mathrm{PbNb}_{2} \mathrm{O}_{6}-\mathrm{BaNb}_{2} \mathrm{O}_{6}$ System, Trans. J. Brit. Ceram. Soc., 71, 11-22 (1972).

9. E. C. Subbarao and G. Shirane, Non-stoichiometry and Ferroelectric Properties of $\mathrm{PbNb}_{2} \mathrm{O}_{6}$-type Compounds, J. Chem. Phys., 32 1846-1851 (1960).

10. M.H. Francombe, The relation between structure and ferroelectricity in lead barium and barium strontium niobates, Acta Cryst. 13, 131 (1960)

11. T. R. Shrout, L. E. Cross and D. Hukin, Ferroelectric Properties of Tungsten Bronze Lead Barium Niobate (PBN) Single Crystals, Ferro. Lett., 44, 325-330 (1983). 
12. C. A. Randall, R. Guo, A. S. Bhalla, and L. E. Cross, Microstructure-property Relations in Tungsten Bronze Lead Barium Niobate, $\mathrm{Pb}_{1-\mathrm{x}} \mathrm{Ba}_{\mathrm{x}} \mathrm{Nb}_{2} \mathrm{O}_{6}$, J. Mater. Res. 6, 1720 (1991).

13. L. A. Bursill and P. J. Lin, Incommensurate Superstructures and Phase Transitions of Strontium Barium Niobate (SBN), Acta Crystallogr. B43, 49-56 (1987)

14. Han-Young Lee and R. Freer, High-Order Incommensurate Modulations and Incommensurate Superstructures in Transparent $\mathrm{Sr}_{0.6} \mathrm{Ba}_{0.4} \mathrm{Nb}_{2} \mathrm{O}_{6}$ (SBN40) Ceramics, J. Appl. Cryst, 31, 683-691 (1998).

15. J. Schneck, J. C. Toledano, R. Whatmore, and F. W. Ainger, Incommensurate Phases in Ferroelectric Tetragonal Tungsten Bronzes, Ferroelectrics, 36, 327 (1981).

16. P. J. Lin and L. A. Bursill, Superlattice Structure of Ferroelectric Barium Sodium Niobate (BNN), Acta Cryst., B43, 504-512 (1987).

17. X. H. Zheng and X. M. Chen, Dielectric Ceramics with Tungsten-Bronze Structure in the $\mathrm{BaO}-\mathrm{Nd}_{2} \mathrm{O}_{3}-\mathrm{TiO}_{2}-\mathrm{Nb}_{2} \mathrm{O}_{5}$ System, J. Mater. Res. 17, 1664-1670 (2002);

18. X. H. Zheng and X. M. Chen, Crystal Structure and Dielectric Properties of Ferroelectric Ceramics in the $\mathrm{BaO}-\mathrm{Sm}_{2} \mathrm{O}_{3}-\mathrm{TiO}_{2}-\mathrm{Nb}_{2} \mathrm{O}_{5}$ System, Solid State Commun. 125, 449-454 (2003).

19. I. Levin, M. C. Stennett, G. C. Miles, D. I. Woodward, A. R. West, and I. M. Reaney, Coupling Between Octahedral Tilting and Ferroelectric Order in Tetragonal Tungsten Bronze-Structured Dielectrics, Appl. Phys. Lett., 89(12) 122908 (2006).

20. M. C. Stennett, I.M. Reaney, G. C. Miles, D. I. Woodward, A. R. West, C. A. Kirk, and I. Levin, Dielectric and Structural Studies of $\mathrm{Ba}_{2} \mathrm{MTi}_{2} \mathrm{Nb}_{3} \mathrm{O}_{15}\left(\mathrm{BMTNO}_{15}, \mathrm{M}=\mathrm{Bi}^{3+}, \mathrm{La}^{3+}\right.$, $\mathrm{Nd}^{3+}, \mathrm{Sm}^{3+}, \mathrm{Gd}^{3+}$ ) Tetragonal Tungsten Bronze-Structured Ceramics, J. Appl. Phys., 101(10), 104114 (2007).

21. T. Ikeda, T. Haraguchi, Y. Onodera and T. Saito, Some Compounds of Tungsten-Bronze Type $\mathrm{A}_{6} \mathrm{~B}_{10} \mathrm{O}_{30}(\mathrm{~B}=\mathrm{Nb}$, Ti or Nb, W) Jpn. J. Appl. Phys., 10, 987 (1971)

22. V. Bovtun, S. Kamba, S. Veljko, D. Nuzhnyy, K. Knížek, M. Savinov, and J. Petzelt, Relaxor-like Behavior of Lead-free $\mathrm{Sr}_{2} \mathrm{LaTi}_{2} \mathrm{Nb}_{3} \mathrm{O}_{15}$ Ceramics with Tetragonal Tungsten Bronze Structure, J. Appl. Phys., 101, 054115 (2007).

23. X.L. Zhu, X.M. Chen, X.Q. Liu and X.G. Li, Dielectric Relaxations, Ultrasonic Attenuation and their Structure Dependence in $\mathrm{Sr}_{4}\left(\mathrm{La}_{\mathrm{x}} \mathrm{Nd}_{1-\mathrm{x}}\right)_{2} \mathrm{Ti}_{4} \mathrm{Nb}_{6} \mathrm{O}_{30}$ Tungsten Bronze Ceramics. J. Mater. Res., 23(11), 3112-3121 (2008).

24. X.L. Zhu and X.M. Chen, Thermal Hysteresis of Ferroelectric Transition in $\mathrm{Sr}_{4} \mathrm{R}_{2} \mathrm{Ti}_{4} \mathrm{Nb}_{6} \mathrm{O}_{30}(\mathrm{R}=\mathrm{Sm} \& \mathrm{Eu})$ Tetragonal Tungsten Bronzes, Appl. Phys. Lett., 96(3), 032901 (2010).

25. X. L. Zhu, X. Q. Liu and X. M. Chen. Crystal Structure and Dielectric Properties of $\mathrm{Sr}_{5} \mathrm{RTi}_{3} \mathrm{Nb}_{7} \mathrm{O}_{30}(\mathrm{R}=\mathrm{La}, \mathrm{Nd}, \mathrm{Sm}$, and $\mathrm{Eu})$ Tungsten Bronze Ceramics. J. Am. Ceram. Soc., 94(6), 1829-1836 (2011).

26. X. L. Zhu and X. M. Chen, Ferroelectric Transition of $\mathrm{Sr}_{5} \mathrm{SmTi}_{3} \mathrm{Nb}_{7} \mathrm{O}_{30}$ Tungsten Bronze Ceramics Investigated by Differential Scanning Calorimetry and Raman Scattering. Journal of the American Ceramic Society, 95(10) 3185-3191 (2012).

27. Ph. Labbé, H. Leligny, B. Raveau, J. Schneck, and J. C. Tolédano, X-ray Structural Determination of the Quasi-commensurate Phase of Barium Sodium Niobate, J. Phys.: Condens. Matter., 2, 25-43 (1989).

28. S. I. Hamazaki, S. Sawada, S Kojima, M. Tsukioka, M. Takashige, Ferroelectric Properties of Tungsten Bronze Oxides with $\mathrm{A}_{2} \mathrm{~A}^{\prime} \mathrm{Ta}_{5} \mathrm{O}_{15}$ Type, J. Phys Soc. Jap., 64(10), 4004-4012 (1995).

29. T.A. Vanderah, W. Febo, J. Y. Chan, R.S. Roth, J.M. Loezos, L.D. Rotter, R.G. Geyer, D.B. Minor, Phase equilibria and dielectric behavior in the $\mathrm{CaO}: \mathrm{Al}_{2} \mathrm{O}_{3}: \mathrm{Nb}_{2} \mathrm{O}_{5}$ system, $\mathrm{J}$. Sol. Stat. Chem., 155, 78-85 (2000) 
30. J. Gardner and F. D. Morrison, A-site Size Effect in a Family of Unfilled Ferroelectric Tetragonal Tungsten Bronzes: $\mathrm{Ba}_{4} \mathrm{R}_{0.67} \mathrm{Nb}_{10} \mathrm{O}_{30}(\mathrm{R}=\mathrm{La}, \mathrm{Nd}, \mathrm{Sm}, \mathrm{Gd}$, Dy and Y), Dalton Trans., 43, 11687-11695 (2014).

31. A. Tkach, P. M. Vilarinho, A. L. Kholkin, I. M. Reaney, J. Pokorny and J. Petzelt, Mechanisms of the Effect of Dopants and $\mathrm{P}\left(\mathrm{O}_{2}\right)$ on the Improper Ferroelastic Phase Transition in $\mathrm{SrTiO}_{3}$, Chem. Mater., 19 (26), 6471-6477 (2007).

32. M. Prades, N. Masó, H. Beltran, E. Cordoncilla, and A. R. West, Synthesis, Structural Characterization, and Electrical Properties of New Oxygen-Deficient Tetragonal Tungsten Bronzes $\mathrm{Ba}_{2} \mathrm{NdTi}_{2+x} \mathrm{Nb}_{3-x} \mathrm{O}_{15-x / 2}$, Inorg. Chem., 52(4), 1729-1736 (2013).

33. B. Kang and G-T Joo, Dielectric Properties of $\mathrm{Sr}_{\mathrm{x}} \mathrm{Ba}_{1-\mathrm{x}} \mathrm{Nb}_{2} \mathrm{O}_{6}$ Ceramics and Single Crystals, J. J. Appl. Phys., 45(8), L245-246 (2006).

34. GP Revkevich, ZK Zolina, LI Ivleva, YS Kuzminov, The Superstructure in Solid-solutions of Ferroelectrics $\mathrm{Ba}_{\mathrm{x}} \mathrm{Sr}_{1-\mathrm{x}} \mathrm{Nb}_{2} \mathrm{O}_{6}$, Kristallografiy, 25, 1069-1069 (1980).

35. R. Guo, A.S. Bhalla, C.A. Randall, and L.E. Cross, Dielectric and Pyroelectric Properties of Lead Barium Niobate (PBN) Single Crystals at Low Temperature (10-300K), J. Appl. Phys., 67(10), 6405-6410 (1990).

36. R. D. Shannon and C. T. Prewitt, Effective ionic radii in oxides and fluorides, Acta Cryst., B25, 925-946 (1969).

37. R. D. Shannon, Dielectric polarizabilities of ions in oxides and fluorides, J. Appl. Phys. 73, 348-366 (1993).

38. Principles and Applications of Ferroelectrics and Related Materials, M. E. Lines and A.M. Glass, Oxford University Press (1977).

39. Y. Yang, Y, Liu, J. Meng, Y. Huan, Y. Wu, Preparation, structure and dielectric properties of $\left(\mathrm{Ba}_{1-\mathrm{x}} \mathrm{Sr}_{\mathrm{x}}\right)_{2} \mathrm{NaNb}_{5} \mathrm{O}_{15}$ ceramics, Journal of Alloys and Compounds, 453, 401-106 (2008)

40. E. Garc1'a-Gonza'lez, A. Torres-Pardo, R. Jime'nez, and J. M. Gonza'lez-Calbet, Structural Singularities in Ferroelectric $\mathrm{Sr}_{2} \mathrm{NaNb}_{5} \mathrm{O}_{15}$, Chem. Mater. 19, 3575-3580 (2007).

41. A. M. Glazer and H. D. Megaw, Studies of the lattice parameters and domains in the phase transitions of $\mathrm{NaNbO}_{3}$, Acta Cryst., A29, 489-495 (1973).

42. M. Josse, O. Bidault, F. Roullana, E. Castel, A. Simon, D. Michau, R. Von der Mühll, O. Nguyen, M. Maglione, The $\mathrm{Ba}_{2} \mathrm{LnFeNb}_{4} \mathrm{O}_{15}$ "Tetragonal Tungsten Bronze": Towards RT Composite Multiferroics, Sol. Stat. Sci., 11(6),1118-1123 (2009).

43. M. Josse,'P. Heijboer, M. Albino, F. Molinari, F. Porcher, R. Decourt, D. Michau, Eric Lebraud, P. Veber, M. Velazque and M. Maglione, Original Crystal-Chemical Behaviors in $(\mathrm{Ba}, \mathrm{Sr})_{2} \mathrm{Ln}(\mathrm{Fe}, \mathrm{Nb}, \mathrm{Ta})_{5} \mathrm{O}_{15}$ Tetragonal Tungsten Bronze: Anion-Driven Properties Evidenced by Cationic Substitutions, Cryst. Growth Des., 14(11), 5428-5435 (2014)

44. B. A. Scott, E. A. Giess, G. Burns, and D. F. O'Kane, Alkali-Rare Earth Niobates with the Tungsten Bronze-Type Structure, Mat. Res. Bull. Vol. 3, 831-842 (1968).

45. N. N. Krainik, V. A. Isupov, M. F. Bryzhina, and A. I. Agranovskaya, Crystal Chemistry of Ferroelectrics with Structural Type of Tetragonal Oxygen Tungsten Bronze, Sov. Phys, Cryst., 9, 281-285 (1964).

46. Y. Gagou, Y. Amira, I. Lukyanchuk, D. Mezzane, M. Courty, C. Masquelier, Yu. I. Yuzyuk and M. El Marssi, On the Nature of Phase Transitions in the Tetragonal Tungsten Bronze $\mathrm{GdK}_{2} \mathrm{Nb}_{5} \mathrm{O}_{15}$ Ceramics, J. Appl. Phys. 115, 064104 (2014).

47. I.M. Reaney, E.L. Colla, N. Setter, Dielectric and Structural characteristics of Ba-based and Sr-Based Complex Perovskites as a Function of Tolerance Factor, J. J. Appl. Phys (Part 1-Regular papers short notes and review papers, 33(7A), 3984-3990 (1994). 
48. R. Ubic, K. Tolman, K. Chan, N. Lundy, S. Letourneau, W.M. Kriven, Effective Size of Vacancies in Aliovalently doped $\mathrm{SrTiO}_{3}$ Perovskites, J Alloys Comp., 575, 239-245 (2013).

49. L. G. Van Uitert, J. J. Rubin, W. H. Grodkiewicz and W. A. Bonner, Some Characteristics of Ba, Sr, Na Niobates, Mat. Res. Bull., 4, 63-74 (1969).

50. N. Stephenson, The crystal structure of the tetragonal tungsten bronze, $\mathrm{Ba}_{6} \mathrm{Ti}_{2} \mathrm{Nb}_{8} \mathrm{O}_{30}$, Acta Cryst., 18, 496-501 (1965)

51. K. Li, X.L. Zhu, X.Q. Liu, and X.M. Chen, Evolution of structure, dielectric properties, and re-entrant relaxor bahaviour in $\mathrm{Ba}_{5} \mathrm{La}_{\mathrm{x}} \mathrm{Sm}_{1-\mathrm{x}} \mathrm{Ti}_{3} \mathrm{Nb}_{7} \mathrm{O}_{30}(\mathrm{x}=0.1,0.25,0.5)$ tungsten bronze ceramics, J. Appl. Phys., 114, 044106, (2013)

52. X.L. Zhu, Y. Bai, X.Q. Liu, and X.M. Chen, Ferroelectric phase transition and low-temperature dielectric relaxations in $\mathrm{Sr}_{4}\left(\mathrm{La}_{1-\mathrm{x}} \mathrm{Sm}_{\mathrm{x}}\right)_{2} \mathrm{Ti}_{4} \mathrm{Nb}_{6} \mathrm{O}_{30}$ ceramics, J. Appl. Phys., 110, 114101 (2011)

53. K. Li, X.L. Zhu, X. Q. Liu, and X. M. Chen, Relaxor ferroelectric characteristics of $\mathrm{Ba}_{5} \mathrm{LaTi}_{3} \mathrm{Nb}_{7} \mathrm{O}_{30}$ tungsten bronze ceramics, Appl. Phys. Lett, 100, 012902 (2012)

54. X.L Zhu, K. Li and X. M. Chen, Ferroelectric Transition and Low-Temperature Dielectric Relaxations in Filled Tungsten Bronzes' J. Am. Ceram. Soc. 97(2), 329-338 (2014). 
Table 1. Composition, crystal-chemical parameters and dielectric behavior for various TTB-structured compounds

\begin{tabular}{|c|c|c|c|c|c|c|c|}
\hline $\begin{array}{c}\text { Formula } \\
\left(\mathrm{O}_{30} \text { for comparison }\right)\end{array}$ & $\begin{array}{l}\text { Stuffed/Filled } \\
\text { /Unfilled }\end{array}$ & $\begin{array}{l}\text { A1-site } \\
\text { disorder }\end{array}$ & $\begin{array}{l}B \text {-site } \\
\text { disorder }\end{array}$ & Commen & $\begin{array}{l}A 1 \text { - site lone } \\
\text { pair }\end{array}$ & $\begin{array}{l}B \text {-site } d^{0} \\
\text { occupancy }\end{array}$ & Relaxor/Ferroelectric \\
\hline $\mathrm{K}_{6} \mathbf{L i}_{4} \mathrm{Nb}_{10} \mathrm{O}_{30}$ & Stuffed & $\mathbf{N}$ & $\mathbf{N}$ & $?$ & $\mathbf{N}$ & 1.0 & Ferroelectric ${ }^{2,3}$ \\
\hline$\left(\mathrm{Pb}_{\mathbf{x}} \mathrm{Ba}_{1-\mathrm{x}}\right)_{5} \mathrm{Nb}_{10} \mathrm{O}_{30}$ & Unfilled & $\mathbf{Y}$ & $\mathbf{N}$ & $\mathbf{N}$ & $\mathbf{Y}$ & 1.0 & Ferroelectric $^{9,11,12}$ \\
\hline$\left(\mathrm{Sr}_{\mathrm{x}} \mathrm{Ba}_{1-\mathrm{x}}\right)_{5} \mathrm{Nb}_{10} \mathrm{O}_{30}$ & Unfilled & $\mathbf{Y}$ & $\mathbf{N}$ & $\mathbf{N}$ & $\mathbf{N}$ & 1.0 & Ferroelectric $(x<0.5)^{4,33}$ \\
\hline $\mathrm{Ba}_{4} \mathrm{Na}_{2} \mathrm{Nb}_{10} \mathrm{O}_{30}$ & Filled & $\mathbf{N}$ & $\mathbf{N}$ & $\mathbf{N}$ & $\mathbf{N}$ & 1.0 & Ferroelectric $^{16,49}$ \\
\hline $\mathrm{Sr}_{4} \mathrm{Na}_{2} \mathrm{Nb}_{10} \mathrm{O}_{30}$ & Filled & $\mathbf{Y}$ & $\mathrm{N}$ & $\mathbf{Y}$ & $\mathbf{N}$ & 1.0 & Ferroelectric $^{40}$ \\
\hline $\mathrm{Ba}_{4} \mathrm{Sm}_{0.67} \mathrm{Nb}_{10} \mathrm{O}_{30}$ & Unfilled & $\mathbf{Y}$ & $\mathbf{N}$ & $\mathbf{Y}$ & $\mathbf{N}$ & 1.0 & Ferroelectric $^{30}$ \\
\hline $\mathrm{Ba}_{6} \mathrm{Ti}_{2} \mathrm{Nb}_{8} \mathrm{O}_{30}$ & Filled & $\mathbf{N}$ & $\mathbf{Y}$ & $?$ & $\mathbf{N}$ & 1.0 & Ferroelectric $^{50}$ \\
\hline $\mathrm{Ba}_{4} \mathrm{Nd}_{2} \mathrm{Ti}_{4} \mathrm{Nb}_{6} \mathrm{O}_{30}$ & Filled & $\mathbf{N}$ & $\mathbf{Y}$ & $\mathbf{Y}$ & $\mathbf{N}$ & 1.0 & Ferroelectric $^{19,20}$ \\
\hline $\mathrm{Ba}_{4} \mathrm{Sm}_{2} \mathrm{Ti}_{4} \mathrm{Nb}_{6} \mathrm{O}_{30}$ & Filled & $\mathbf{N}$ & $\mathbf{Y}$ & $\mathbf{Y}$ & $\mathbf{N}$ & 1.0 & Ferroelectric ${ }^{20}$ \\
\hline $\mathrm{Ba}_{4} \mathrm{Gd}_{2} \mathrm{Ti}_{4} \mathrm{Nb}_{6} \mathrm{O}_{30}$ & Filled & $\mathbf{N}$ & $\mathbf{Y}$ & $\mathbf{Y}$ & $\mathbf{N}$ & 1.0 & Ferroelectric $^{20}$ \\
\hline $\mathrm{Ba}_{4} \mathrm{Nd}_{2} \mathrm{Fe}_{2} \mathrm{Nb}_{8} \mathrm{O}_{30}$ & Filled & $\mathbf{N}$ & $\mathbf{Y}$ & $?$ & $\mathbf{N}$ & 0.8 & Ferroelectric $^{42,43}$ \\
\hline $\mathrm{Ba}_{4} \mathrm{Sm}_{2} \mathrm{Fe}_{2} \mathrm{Nb}_{8} \mathrm{O}_{30}$ & Filled & $\mathbf{N}$ & $\mathbf{Y}$ & $?$ & $\mathbf{N}$ & 0.8 & Ferroelectric ${ }^{42,43}$ \\
\hline $\mathrm{Ba}_{4} \mathrm{Dy}_{0.67} \mathrm{Nb}_{10} \mathrm{O}_{30}$ & Empty & $\mathbf{Y}$ & $\mathbf{N}$ & $?$ & $\mathbf{N}$ & 1.0 & Ferroelectric $^{30}$ \\
\hline $\mathrm{Ba}_{3.875} \mathrm{Dy}_{0.75} \mathrm{Nb}_{10} \mathrm{O}_{30}$ & Empty & $\mathbf{Y}$ & $\mathbf{N}$ & $?$ & $\mathrm{~N}$ & 1.0 & Ferroelectric \\
\hline $\mathrm{Ba}_{3.75} \mathrm{Dy}_{0.83} \mathrm{Nb}_{10} \mathrm{O}_{30}$ & Empty & $\mathbf{Y}$ & $\mathbf{N}$ & $?$ & $\mathbf{N}$ & 1.0 & Ferroelectric \\
\hline $\mathrm{Ba}_{4} \mathbf{Y}_{0.67} \mathrm{Nb}_{10} \mathrm{O}_{30}$ & Empty & $\mathbf{Y}$ & $\mathbf{N}$ & $?$ & $\mathbf{N}$ & 1.0 & Ferroelectric $^{30}$ \\
\hline $\mathrm{Ba}_{4} \mathrm{Sm}_{0.67} \mathrm{Nb}_{10} \mathrm{O}_{30}$ & Empty & $\mathbf{Y}$ & $\mathrm{N}$ & $?$ & $\mathbf{N}$ & 1.0 & Ferroelectric $^{30}$ \\
\hline $\mathrm{K}_{4} \mathrm{Nd}_{2} \mathrm{Nb}_{10} \mathrm{O}_{30}$ & Filled & $\mathbf{N}$ & $\mathbf{N}$ & $?$ & $\mathrm{~N}$ & 1.0 & Ferrolectric $^{44}$ \\
\hline $\mathbf{K}_{4} \mathbf{B i}_{2} \mathrm{Nb}_{10} \mathrm{O}_{30}$ & Filled & $\mathbf{N}$ & $\mathbf{N}$ & $?$ & $\mathbf{Y}$ & 1.0 & Ferroelectric $^{45}$ \\
\hline $\mathrm{Sr}_{5} \mathrm{EuTi}_{3} \mathrm{Nb}_{7} \mathrm{O}_{30}$ & Filled & $\mathbf{Y}$ & $\mathbf{Y}$ & $\mathbf{Y}$ & $\mathrm{N}$ & 1.0 & Ferroelectric $^{25}$ \\
\hline $\mathrm{Sr}_{5} \mathrm{SmTi}_{3} \mathrm{Nb}_{7} \mathrm{O}_{30}$ & Filled & $\mathbf{Y}$ & $\mathbf{Y}$ & $\mathbf{Y}$ & $\mathrm{N}$ & 1.0 & Ferroelectric $^{25}$ \\
\hline $\mathrm{Ba}_{4} \mathrm{Nd}_{0.67} \mathrm{Nb}_{10} \mathrm{O}_{30}$ & Empty & $\mathbf{Y}$ & $\mathbf{N}$ & $\mathbf{N}$ & $\mathrm{N}$ & 1.0 & Ferroelectric $^{30}$ \\
\hline $\mathbf{B a}_{4} \mathbf{L a}_{0.67} \mathbf{N b}_{10} \mathbf{O}_{30}$ & Empty & $\mathbf{Y}$ & $\mathbf{N}$ & $\mathbf{Y}$ & $\mathrm{N}$ & 1.0 & Relaxor/Ferroelectric $^{30}$ \\
\hline $\mathrm{Sr}_{5} \mathrm{NdTi}_{3} \mathrm{Nb}_{7} \mathrm{O}_{30}$ & Filled & $\mathbf{Y}$ & $\mathbf{Y}$ & $\mathbf{Y}$ & $\mathbf{N}$ & 1.0 & Relaxor/ferroelectric ${ }^{25}$ \\
\hline $\mathrm{Ba}_{5} \mathrm{La}_{0.5} \mathrm{Sm}_{0.5} \mathrm{Ti}_{3} \mathrm{Nb}_{7} \mathrm{O}_{30}$ & Filled & $\mathbf{Y}$ & $\mathbf{Y}$ & $?$ & $\mathrm{~N}$ & 1.0 & Relaxor $^{51}$ \\
\hline $\mathrm{Ba}_{5} \mathrm{La}_{0.25} \mathrm{Sm}_{0.75} \mathrm{Ti}_{3} \mathrm{Nb}_{7} \mathrm{O}_{30}$ & Filled & $\mathbf{Y}$ & $\mathbf{Y}$ & $?$ & $\mathbf{N}$ & 1.0 & Relaxor $^{51}$ \\
\hline $\mathrm{Ba}_{5} \mathrm{La}_{0.1} \mathrm{Sm}_{0.9} \mathrm{Ti}_{3} \mathrm{Nb}_{7} \mathrm{O}_{30}$ & Filled & $\mathbf{Y}$ & $\mathbf{Y}$ & $?$ & $\mathbf{N}$ & 1.0 & Relaxor $^{51}$ \\
\hline $\mathbf{K}_{4} \mathbf{L a}_{2} \mathbf{N b}_{10} \mathbf{O}_{30}$ & Filled & $\mathrm{N}$ & $\mathbf{N}$ & $?$ & $\mathrm{~N}$ & 1.0 & Relaxor $^{44}$ \\
\hline $\mathrm{Ba}_{4} \mathrm{Pr}_{2} \mathrm{Fe}_{2} \mathrm{Nb}_{8} \mathrm{O}_{30}$ & Filled & $\mathbf{N}$ & $\mathbf{Y}$ & $?$ & $\mathbf{N}$ & 0.8 & Relaxor $^{42}$ \\
\hline$\left(\mathrm{Sr}_{\mathrm{x}} \mathrm{Ba}_{1-\mathrm{x}}\right)_{5} \mathrm{Nb}_{10} \mathrm{O}_{30}$ & Unfilled & $\mathbf{Y}$ & $\mathbf{N}$ & $\mathrm{N}$ & $\mathbf{N}$ & 1.0 & Relaxor $(x>0.5)^{4,33}$ \\
\hline $\mathrm{Ba}_{4} \mathrm{Bi}_{2} \mathrm{Ti}_{4} \mathrm{Nb}_{6} \mathrm{O}_{30}$ & Filled & $\mathbf{N}$ & $\mathbf{Y}$ & $\mathbf{N}$ & $\mathbf{Y}$ & 1.0 & Relaxor $^{20}$ \\
\hline $\mathbf{B a}_{4} \mathbf{L a}_{2} \mathrm{Ti}_{4} \mathrm{Nb}_{6} \mathrm{O}_{30}$ & Filled & $\mathbf{N}$ & $\mathbf{Y}$ & $\mathbf{N}$ & $\mathbf{N}$ & 1.0 & Relaxor $^{20}$ \\
\hline $\mathrm{Sr}_{5} \mathrm{LaTi}_{3} \mathrm{Nb}_{7} \mathrm{O}_{30}$ & Filled & $\mathbf{Y}$ & $\mathbf{Y}$ & $\mathbf{N}$ & $\mathbf{N}$ & 1.0 & Relaxor $^{25}$ \\
\hline
\end{tabular}


Table 2. Polarizability and radii for the pertinent ions in TTB-structured ceramics. * indicates where the radius has been extrapolated form lower coordinations. Ionic radii are adopted from Shannon and Prewitt ${ }^{36}$ and polarizabilities from Shannon ${ }^{37}$.

\begin{tabular}{|c|c|c|c|c|}
\hline Ion Type & Polarizability $\left(\AA^{3}\right)$ & Radius CN15 $(\AA)$ & Radius CN12 $(\AA)$ & Radius CN6 $(\AA)$ \\
\hline $\mathbf{R b}^{+}$ & 5.29 & $2^{*}$ & 1.88 & \\
\hline $\mathbf{C s}+$ & 7.43 & $1.85^{*}$ & 1.72 & \\
\hline $\mathbf{K}^{+}$ & 3.83 & $1.7^{*}$ & 1.64 & \\
\hline $\mathbf{N a}^{+}$ & 1.8 & $1.45^{*}$ & 1.39 & \\
\hline $\mathbf{B a}^{2+}$ & 6.4 & $1.65^{*}$ & 1.61 & \\
\hline $\mathbf{S r}^{2+}$ & 4.24 & $1.5^{*}$ & 1.44 & \\
\hline $\mathbf{P b}^{2+}$ & 6.58 & $1.55^{*}$ & 1.49 & \\
\hline $\mathbf{B i}^{3+}$ & 6.12 & & $1.36^{*}$ & \\
\hline $\mathbf{L a}^{3+}$ & 6.05 & & 1.36 & \\
\hline $\mathbf{P r}^{3+}$ & 5.32 & & 1.32 & \\
\hline $\mathbf{N d}^{3+}$ & 5.01 & & 1.27 & \\
\hline $\mathbf{S m}^{3+}$ & 4.74 & & 1.24 & \\
\hline $\mathbf{E u}^{3+}$ & 4.53 & & $1.21^{*}$ & \\
\hline $\mathbf{G d}^{3+}$ & 4.37 & & $1.19^{*}$ & \\
\hline $\mathrm{Nb}^{5+}$ & 3.97 & & & 0.64 \\
\hline $\mathrm{Ta}^{5+}$ & 4.73 & & & 0.64 \\
\hline $\mathrm{Ti}^{4+}$ & 2.93 & & & 0.61 \\
\hline $\mathrm{Fe}^{3+}$ & 2.29 & & & 0.61 \\
\hline
\end{tabular}


Table 3. $A 1$ tolerance factor and average $((A 1+A 2) / 2)$ site radii for TTB compounds. Ionic radii are adopted from Shannon and Prewitt. ${ }^{36}$

\begin{tabular}{|c|c|c|c|c|c|}
\hline & Compound & $t_{A 1}$ factor & $(A 1+A 2) / 2$ & Average $O-B-O$ & ref \\
\hline $\mathbf{F}$ & $\mathrm{K}_{6} \mathrm{Li}_{4} \mathrm{Nb}_{10} \mathrm{O}_{30}$ & 1.07 & 1.67 & & 2,3 \\
\hline $\mathbf{F}$ & $\mathrm{Pb}_{5} \mathrm{Nb}_{10} \mathrm{O}_{30}$ & 1.01 & 1.52 & & $9,10,11,12$ \\
\hline $\mathbf{F}$ & $\left(\mathrm{Pb}_{0.5} \mathrm{Ba}_{0.5}\right)_{5} \mathrm{Nb}_{10} \mathrm{O}_{30}$ & 1.04 & 1.60 & & $9,10,11,12$ \\
\hline $\mathbf{F}$ & $\mathrm{Ba}_{5} \mathrm{Nb}_{10} \mathrm{O}_{30}$ & 1.05 & 1.64 & & 4,33 \\
\hline $\mathbf{F}$ & $\mathrm{Ba}_{6} \mathrm{Ti}_{2} \mathrm{Nb}_{8} \mathrm{O}_{30}$ & 1.06 & 1.64 & 4.02 & 50 \\
\hline $\mathbf{F}$ & $\left(\mathrm{Sr}_{0.33} \mathrm{Ba}_{0.67}\right)_{5} \mathrm{Nb}_{10} \mathrm{O}_{30}$ & 1.03 & 1.59 & & 4,33 \\
\hline $\mathbf{F}$ & $\mathrm{Ba}_{4} \mathrm{Na}_{2} \mathrm{Nb}_{10} \mathrm{O}_{30}$ & 0.98 & 1.53 & 4.03 & $16,27,49$ \\
\hline $\mathbf{F}$ & $\mathrm{Sr}_{4} \mathrm{Na}_{2} \mathrm{Nb}_{10} \mathrm{O}_{30}$ & 0.99 & 1.45 & & 40 \\
\hline $\mathbf{F}$ & $\mathrm{Ba}_{4} \mathrm{Y}_{0.67} \mathrm{Nb}_{10} \mathrm{O}_{30}$ & 0.89 & 1.42 & 3.96 & 30 \\
\hline $\mathbf{F}$ & $\mathrm{Ba}_{4} \mathrm{Dy}_{0.67} \mathrm{Nb}_{10} \mathrm{O}_{30}$ & 0.90 & 1.42 & 3.96 & 30 \\
\hline $\mathbf{F}$ & $\mathrm{Ba}_{3.875} \mathrm{Dy}_{0.75} \mathrm{Nb}_{10} \mathrm{O}_{30}$ & 0.90 & 1.42 & 3.95 & \\
\hline $\mathbf{F}$ & $\mathrm{Ba}_{3.75} \mathrm{Dy}_{0.83} \mathrm{Nb}_{10} \mathrm{O}_{30}$ & 0.90 & 1.42 & 3.95 & \\
\hline $\mathbf{F}$ & $\mathrm{Ba}_{4} \mathrm{Sm}_{0.67} \mathrm{Nb}_{10} \mathrm{O}_{30}$ & 0.92 & 1.46 & & 30 \\
\hline $\mathbf{F}$ & $\mathrm{Ba}_{4} \mathrm{Nd}_{\mathbf{0 . 6 7}} \mathrm{Nb}_{10} \mathrm{O}_{30}$ & 0.93 & 1.47 & 3.96 & 30 \\
\hline $\mathbf{F}$ & $\mathrm{Sr}_{4} \mathrm{Sm}_{2} \mathrm{Ti}_{4} \mathrm{Nb}_{6} \mathrm{O}_{30}$ & 0.93 & 1.37 & 3.88 & $23,24,52$ \\
\hline $\mathbf{F}$ & $\mathrm{Sr}_{4} \mathrm{Nd}_{2} \mathrm{Ti}_{4} \mathrm{Nb}_{6} \mathrm{O}_{30}$ & 0.94 & 1.39 & 3.87 & 23,24 \\
\hline $\mathbf{F}$ & $\mathrm{Sr}_{\mathbf{5}} \mathrm{EuTi}_{\mathbf{3}} \mathbf{N b}_{\mathbf{7}} \mathbf{O}_{\mathbf{3 0}}$ & 0.96 & 1.41 & 3.89 & 25 \\
\hline $\mathbf{F}$ & $\mathrm{Sr}_{5} \mathrm{SmTi}_{3} \mathrm{Nb}_{7} \mathrm{O}_{30}$ & 0.96 & 1.42 & 3.89 & 25 \\
\hline $\mathbf{F}$ & $\mathrm{Ba}_{4} \mathrm{Nd}_{2} \mathrm{Ti}_{4} \mathrm{Nb}_{6} \mathrm{O}_{30}$ & 0.94 & 1.47 & & 19,20 \\
\hline $\mathbf{F}$ & $\mathrm{Ba}_{4} \mathrm{Sm}_{2} \mathrm{Ti}_{4} \mathrm{Nb}_{6} \mathrm{O}_{30}$ & 0.93 & 1.46 & & 20 \\
\hline $\mathbf{F}$ & $\mathrm{Ba}_{4} \mathrm{Gd}_{2} \mathrm{Ti}_{4} \mathrm{Nb}_{6} \mathrm{O}_{30}$ & 0.91 & 1.43 & & 20 \\
\hline $\mathbf{F}$ & $\mathrm{Ba}_{4} \mathrm{Nd}_{2} \mathrm{Fe}_{2} \mathrm{Nb}_{8} \mathrm{O}_{30}$ & 0.93 & 1.47 & & 42,43 \\
\hline $\mathbf{F}$ & $\mathrm{Ba}_{4} \mathrm{Sm}_{2} \mathrm{Fe}_{2} \mathrm{Nb}_{8} \mathrm{O}_{30}$ & 0.92 & 1.46 & & 42,43 \\
\hline $\mathbf{F}$ & $\mathrm{K}_{4} \mathbf{G d}_{2} \mathrm{Nb}_{10} \mathrm{O}_{30}$ & 0.91 & 1.45 & & 44,45 \\
\hline $\mathbf{R}$ & $\mathrm{Sr}_{4} \mathrm{La}_{2} \mathrm{Ti}_{4} \mathrm{Nb}_{6} \mathrm{O}_{30}$ & 0.97 & 1.43 & 3.87 & $22,23,24$ \\
\hline $\mathbf{R}$ & $\mathrm{Sr}_{5} \mathrm{NdTi}_{3} \mathrm{Nb}_{7} \mathrm{O}_{30}$ & 0.97 & 1.43 & 3.89 & 25 \\
\hline $\mathbf{R}$ & $\mathrm{K}_{4} \mathrm{La}_{2} \mathrm{Nb}_{10} \mathrm{O}_{30}$ & 0.97 & 1.53 & & 44 \\
\hline $\mathbf{R}$ & $\mathrm{Ba}_{4} \mathrm{La}_{2} \mathrm{Fe}_{2} \mathrm{Nb}_{8} \mathrm{O}_{30}$ & 0.97 & 1.52 & & 42,43 \\
\hline $\mathbf{R}$ & $\mathrm{Ba}_{4} \mathrm{Pr}_{2} \mathrm{Fe}_{2} \mathrm{Nb}_{8} \mathrm{O}_{30}$ & 0.95 & 1.50 & & 42,43 \\
\hline $\mathbf{R}$ & $\mathrm{Ba}_{4} \mathrm{Bi}_{2} \mathrm{Ti}_{4} \mathrm{Nb}_{6} \mathrm{O}_{30}$ & 0.97 & 1.52 & & 20 \\
\hline $\mathbf{R}$ & $\mathrm{Ba}_{4} \mathbf{L a}_{2} \mathrm{Ti}_{4} \mathrm{Nb}_{6} \mathrm{O}_{30}$ & 0.97 & 1.52 & 3.93 & 20 \\
\hline $\mathbf{R}$ & $\mathrm{Ba}_{4} \mathrm{La}_{0.67} \mathrm{Nb}_{10} \mathrm{O}_{30}$ & 0.97 & 1.52 & 3.96 & 30 \\
\hline $\mathbf{R}$ & $\mathrm{Ba}_{5} \mathrm{LaTi}_{3} \mathrm{Nb}_{7} \mathrm{O}_{30}$ & 1.02 & 1.58 & 3.96 & 53 \\
\hline $\mathbf{R}$ & $\mathrm{Ba}_{5} \mathbf{L a}_{0.5} \mathrm{Sm}_{0.5} \mathrm{Ti}_{3} \mathrm{Nb}_{7} \mathrm{O}_{30}$ & 1.00 & 1.56 & 3.95 & 51 \\
\hline $\mathbf{R}$ & $\mathbf{B a}_{5} \mathbf{L a}_{0.25} \mathbf{S m}_{0.75} \mathrm{Ti}_{3} \mathbf{N b}_{7} \mathrm{O}_{30}$ & 1.00 & 1.56 & 3.95 & 51 \\
\hline $\mathbf{R}$ & $\mathrm{Ba}_{5} \mathbf{L a}_{0.1} \mathrm{Sm}_{0.9} \mathrm{Ti}_{3} \mathrm{Nb}_{7} \mathrm{O}_{30}$ & 1.00 & 1.55 & 3.95 & 51 \\
\hline $\mathbf{R}$ & $\mathrm{Sr}_{5} \mathrm{LaTi}_{3} \mathrm{Nb}_{7} \mathrm{O}_{30}$ & 0.99 & 1.45 & 3.90 & 25,26 \\
\hline $\mathbf{R}$ & $\mathrm{Sr}_{5} \mathrm{Nb}_{10} \mathrm{O}_{30}$ & 0.99 & 1.47 & & 4,33 \\
\hline
\end{tabular}




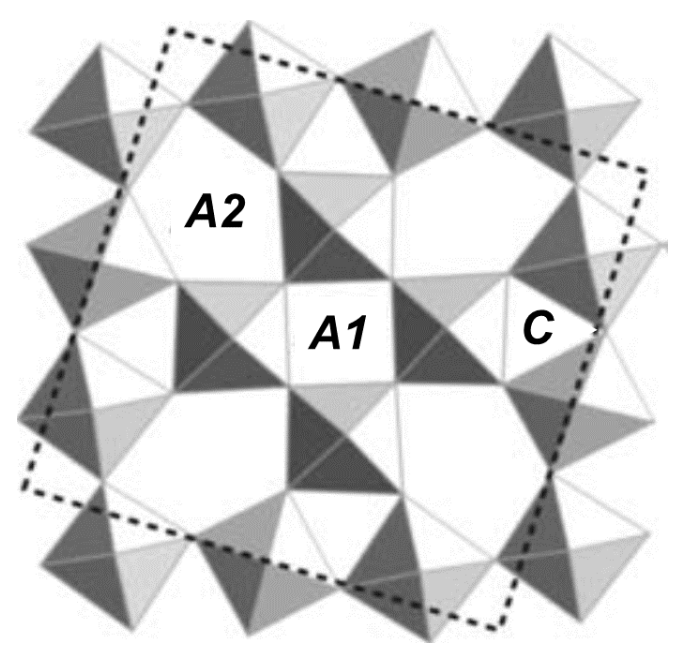

Figure 1. [001] projection of the prototype tetragonal tungsten bronze structure illustrating the interstices described by corner sharing octahedra, after Levin and coworkers. ${ }^{19}$

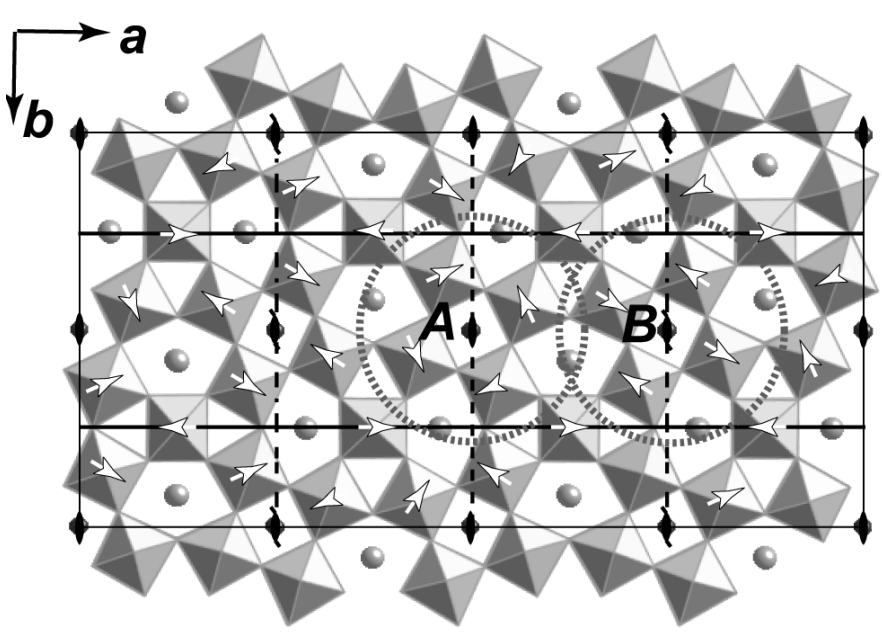

Ama2

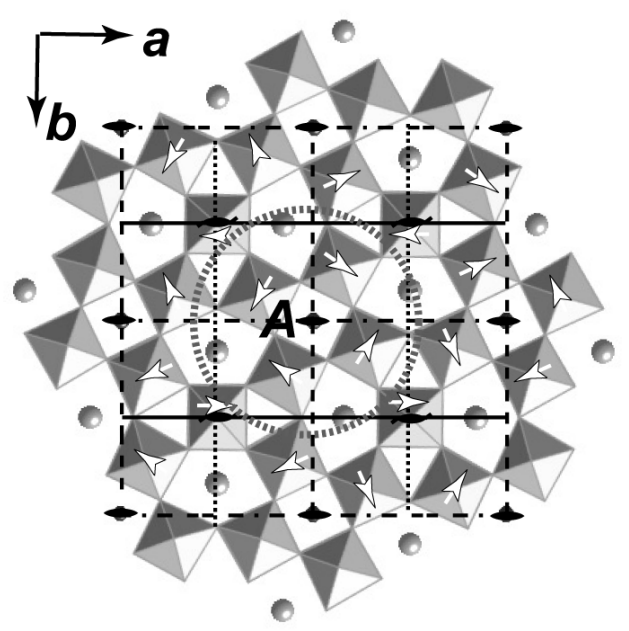

Ima2

Figure 2 a) $a \approx 2 \sqrt{ } 2 a_{T T B}, b \approx \sqrt{ } 2 a_{T T B}$ and $c \approx 2 c_{\mathrm{TTB}}$ cell used as an approximant of the incommensurate superstructure and b) commensurate $a \approx \sqrt{ } 2 a_{T T B}, b \approx \sqrt{ } 2 a_{T T B}$ and $c \approx 2 c_{T T B}$, cell, after Levin and coworkers. ${ }^{19}$ 

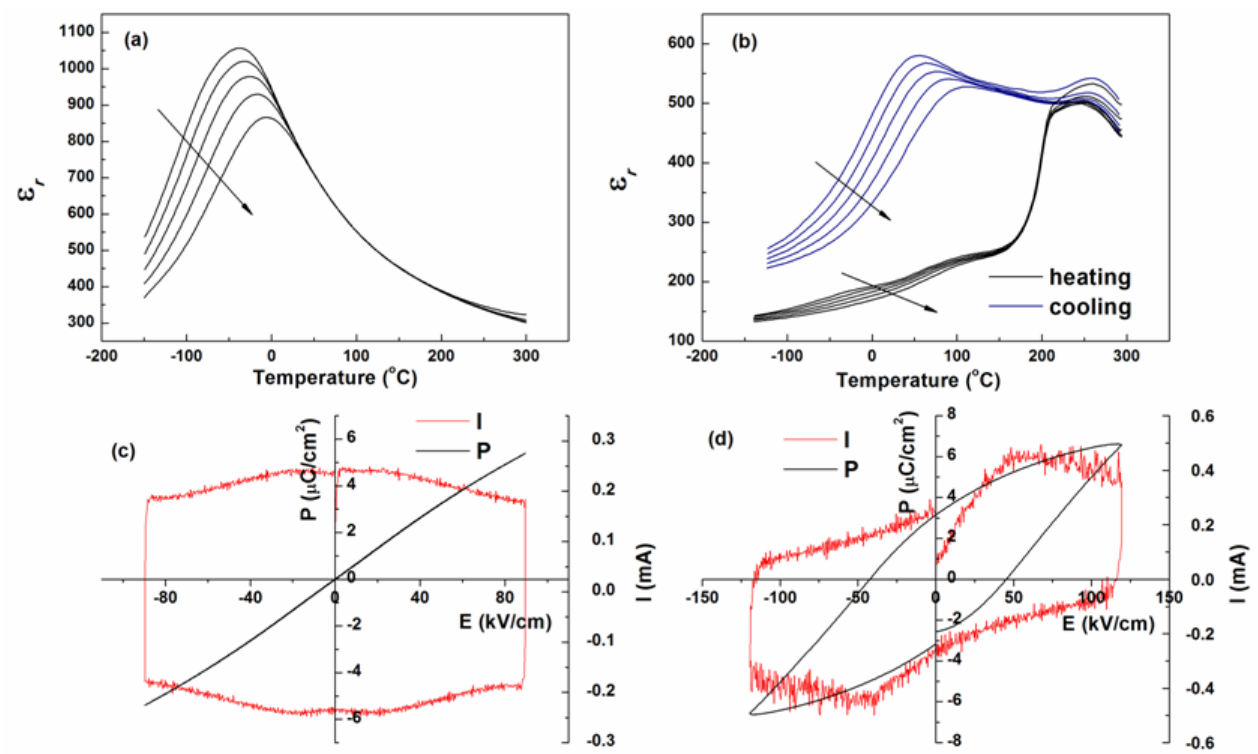

Fig. 3 (a) and (b) Temperature and frequency dependences of relative permittivity $\varepsilon_{\text {r }}$; arrows indicate the increasing frequency from $100 \mathrm{~Hz}$ to $1 \mathrm{MHz}$;(c) and (d) room temperature hysteresis loops and I-E curves for $\mathrm{Sr}_{5} \mathrm{LaTi}_{3} \mathrm{Nb}_{7} \mathrm{O}_{30}$ and $\mathrm{Sr}_{5} \mathrm{SmTi}_{3} \mathrm{Nb}_{7} \mathrm{O}_{30}$, respectively.

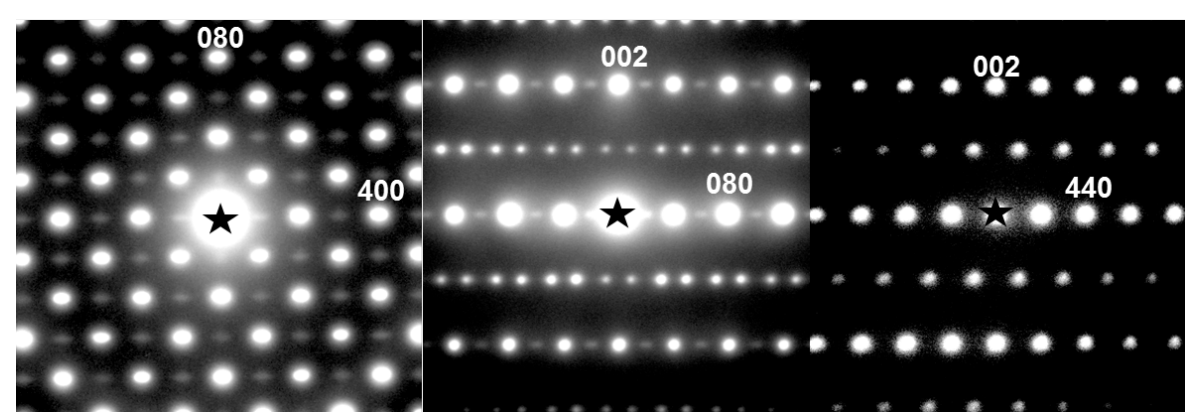

Fig. 4 Experimental zone axis electron diffraction patterns (ZADP) from $\mathrm{Sr}_{5} \mathrm{LaTi}_{3} \mathrm{Nb}_{7} \mathrm{O}_{30}$ with the electron beam parallel to the following directions of the prototypical tetragonal TTB structure a) [001] (Bbm2, $a \approx 2 \sqrt{2} a_{T T B}, b \approx \sqrt{ } 2 a_{T T B}$ and $\left.\left.c \approx 2 c_{T T B}\right), \mathrm{b}\right)$ [100] (Bbm2, $a \approx$ $2 \sqrt{ } 2 a_{T T B}, b \approx \sqrt{ } 2 a_{T T B}$ and $\left.c \approx 2 c_{T T B}\right)$, and c) [1-10] from $\operatorname{Sr}_{5} \operatorname{SmTi}_{3} \mathrm{Nb}_{7} \mathrm{O}_{30}\left(\operatorname{Ima} 2, a \approx \sqrt{ } 2 a_{T T B}, b\right.$ $\approx \sqrt{ } 2 a_{T T B}$ and $c \approx 2 c_{T T B}$ ). 


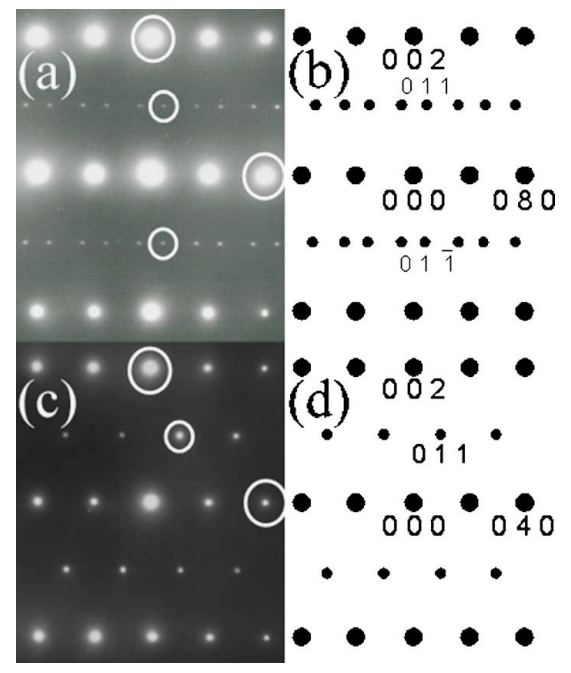

Figure 5. Zone axis diffraction patterns from a) $\mathrm{Ba}_{4} \mathrm{La}_{2} \mathrm{Ti}_{4} \mathrm{Nb}_{6} \mathrm{O}_{30}$ indexed as b) [100] (Ama2, $a \approx \sqrt{ } 2 a_{T T B}, b \approx 2 \sqrt{2} a_{T T B}$ and $c \approx 2 c_{T T B}$ ) and c) $\mathrm{Ba}_{4} \mathrm{Nd}_{2} \mathrm{Ti}_{4} \mathrm{Nb}_{6} \mathrm{O}_{30}$ indexed as d) [100] (Ima2, $a$ $\approx \sqrt{ } 2 a_{T T B}, b \approx \sqrt{ } 2 a_{T T B}$ and $c \approx 2 c_{T T B}$, , after Stennett et al. ${ }^{20}$

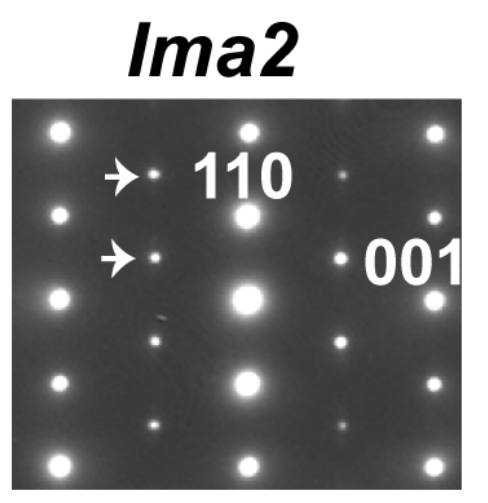

$423 \mathrm{~K}$

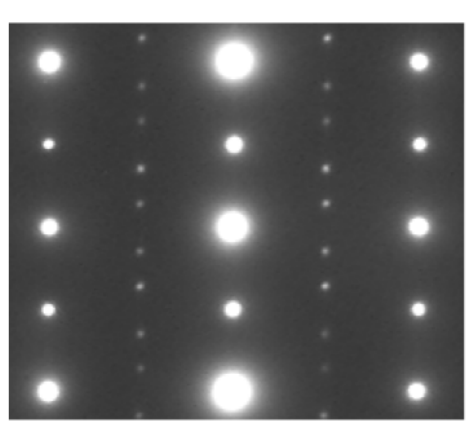

$673 \mathrm{~K}$

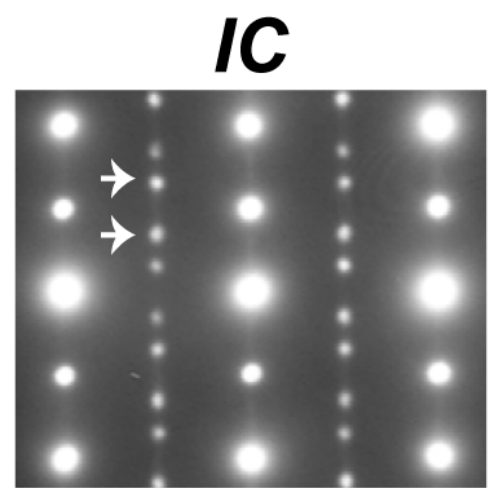

$453 \mathrm{~K}$

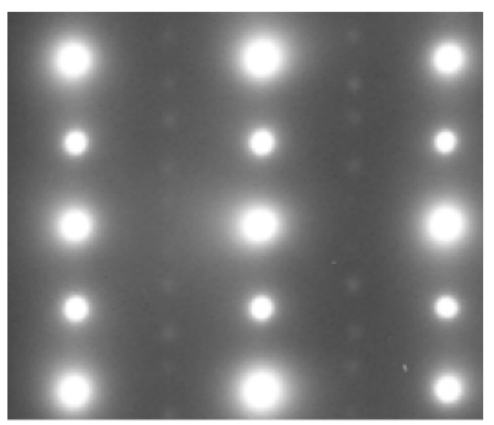

$733 \mathrm{~K}$

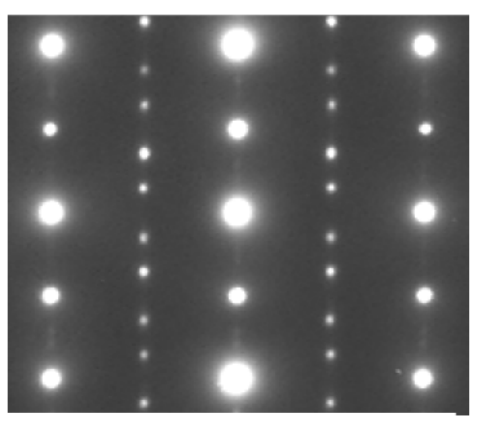

$603 \mathrm{~K}$

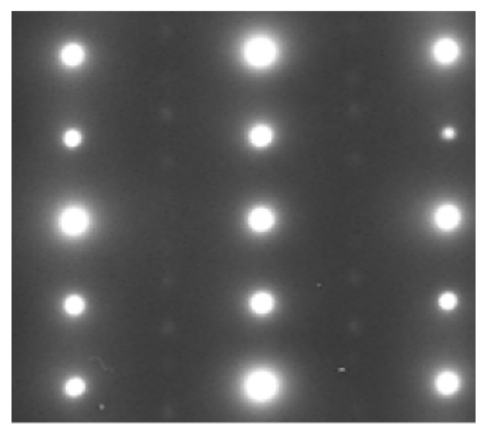

$823 \mathrm{~K}$

Figure 6. $<110>_{T T B} \mathrm{ZADPs}$ obtained as a function of temperature for $\mathrm{Ba}_{4} \mathrm{Nd}_{2} \mathrm{Ti}_{4} \mathrm{Nb}_{6} \mathrm{O}_{30}$ which reveals a commensurate - incommensurate transition coincident with the paraelectric to ferroelectric transition at $\sim 433 \mathrm{~K}$, after Levin et al. ${ }^{19}$. Indexation is in the prototype TTB cell. 


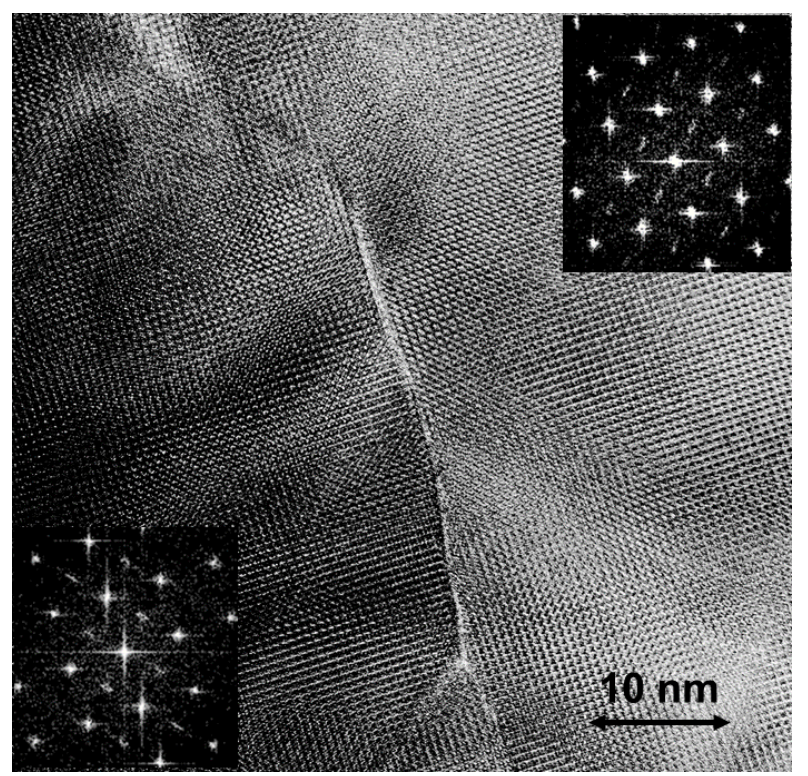

Fig.7. High resolution TEM image for $\mathrm{Sr}_{5} \mathrm{LaTi}_{3} \mathrm{Nb}_{7} \mathrm{O}_{30}$ ceramics with [001] ттв zone axis. Insets are the corresponding FT images on either side of the main defect. Note the changes in the direction of incommensurate splitting from $[110]_{\text {TТВ }}$ to $[1-10]_{\text {ТTВ }}$ across the boundary.

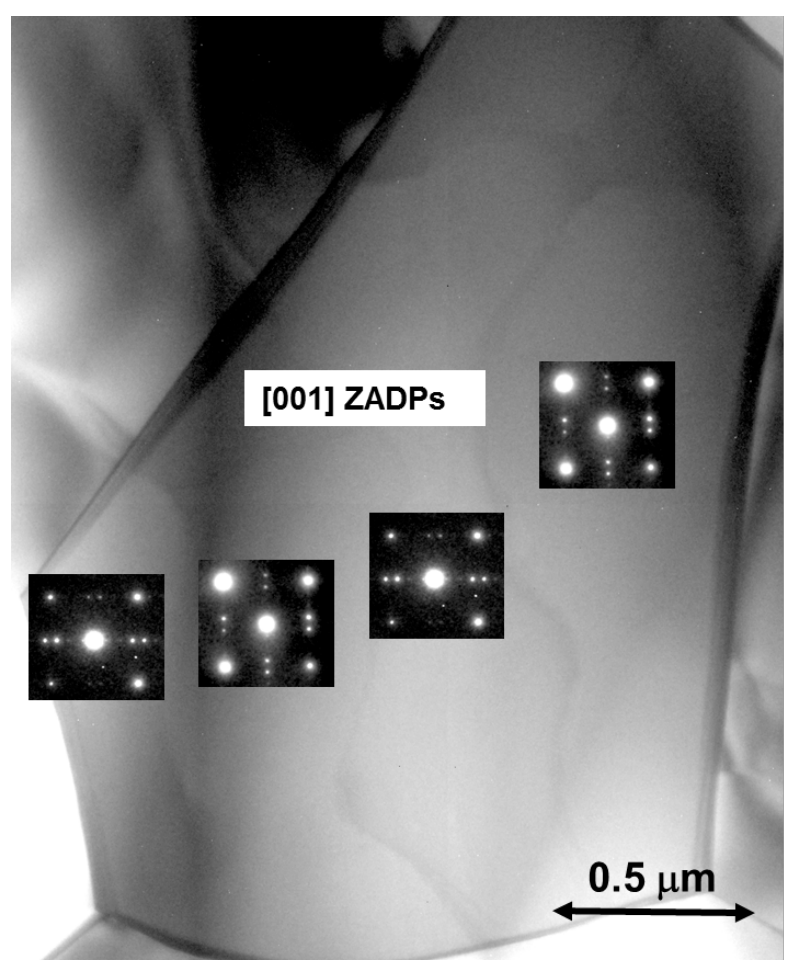

Fig. 8. Bright field image of $\mathrm{Sr}_{4} \mathrm{La}_{2} \mathrm{Ti}_{4} \mathrm{Nb}_{6} \mathrm{O}_{30}$ ceramic. Note the changes in the direction of incommensurate splitting from $[110]_{T T B}$ to $[1-10]_{\text {TTB }}$ in alternate incommensurate domains whose walls exhibit weak diffraction contrast. 


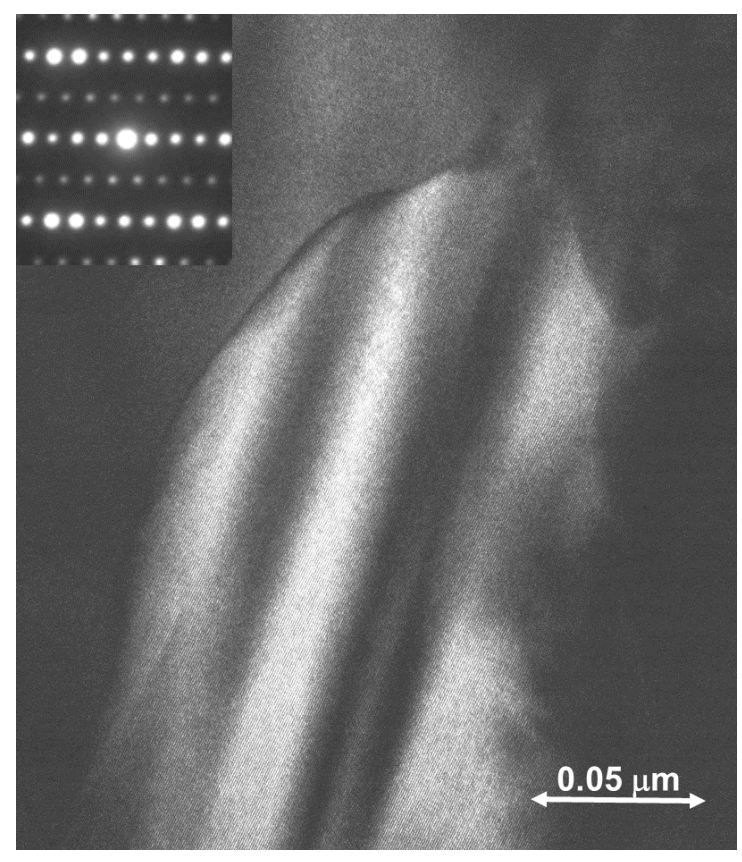

Fig.9. Dark field TEM image of a grain $\mathrm{Sr}_{5} \mathrm{SmTi}_{3} \mathrm{Nb}_{7} \mathrm{O}_{30}$ recorded near the [100] $]_{\text {TTB }}$ zone axis using the commensurate superlattice reflection; inset shows the $[100]_{T T B}$ SADP. The planar defects are similar to those reported by Stennett et al. ${ }^{20}$ for $\mathrm{Ba}_{4} \mathrm{RE}_{2} \mathrm{Ti}_{4} \mathrm{Nb}_{6} \mathrm{O}_{30}(\mathrm{RE}=\mathrm{Nd}, \mathrm{Sm}$, Gd).
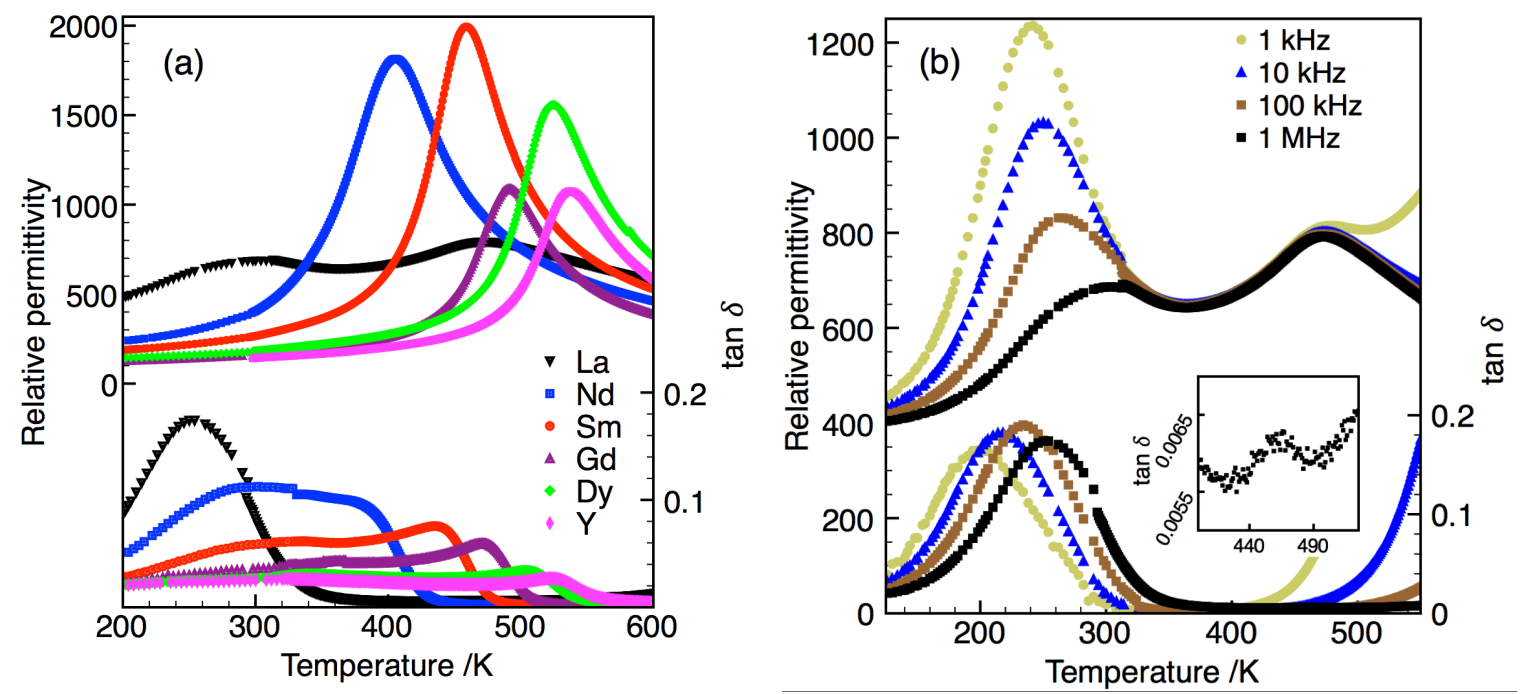

Figure 10. Relative permittivity and loss $(\tan \delta)$ at $1 \mathrm{MHz}$ versus temperature plot for (a) $\mathrm{Ba}_{4} \mathrm{RE}_{0.67}{ }_{1.33} \mathrm{Nb}_{10} \mathrm{O}_{30}, \mathrm{RE}=\mathrm{La}, \mathrm{Nd}, \mathrm{Sm}, \mathrm{Gd}$, Dy Y) ceramics, and (b) frequency dependent data for $\mathrm{Ba}_{4} \mathrm{RE}_{0.67} \quad{ }_{1.33} \mathrm{Nb}_{10} \mathrm{O}_{30}$, according to Gardner and Morrison ${ }^{30}$. 

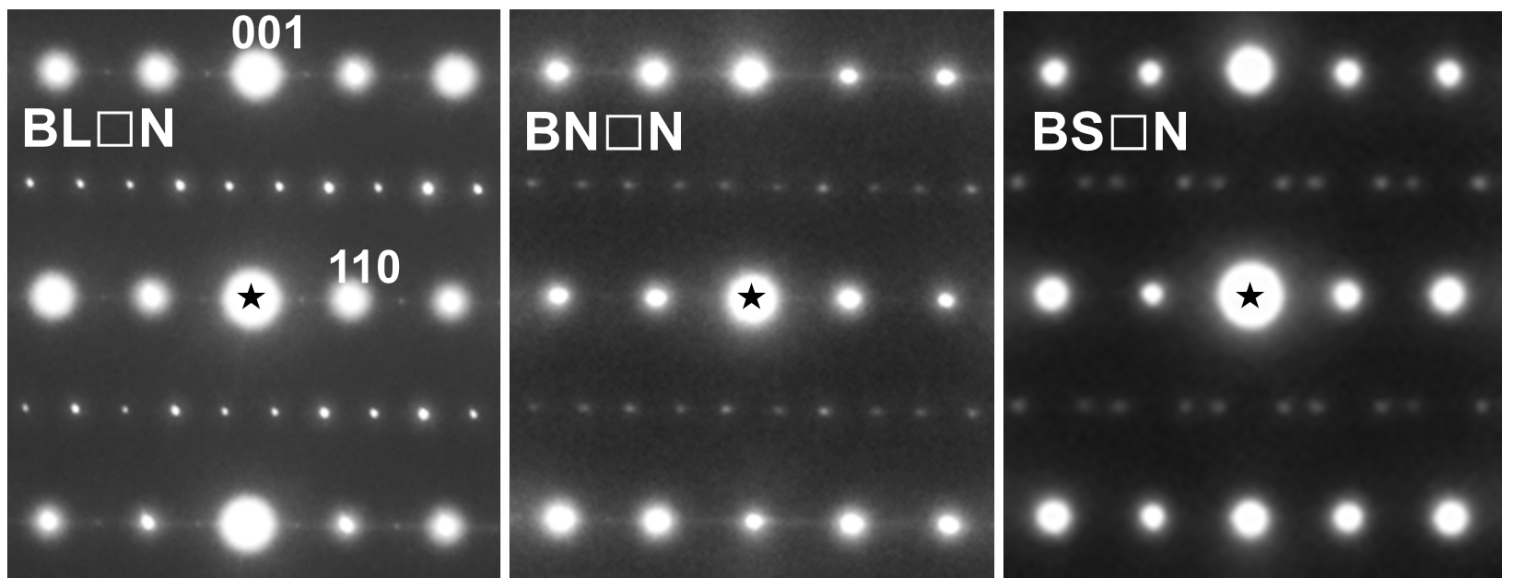

Figure 11. $<110>_{T T B}$ zone axis electron diffraction patterns for $\mathrm{Ba}_{4} \mathrm{RE}_{0.67}{ }_{1.33} \mathrm{Nb}_{10} \mathrm{O}_{30}$ $(\mathrm{BRE} \mathrm{N})(\mathrm{RE}=\mathrm{La}$ and $\mathrm{Nd})$ ceramics. BL $\mathrm{N}$ exhibits a commensurate cell with $a \approx 2 \sqrt{ } 2 a_{T T B}$, $b \approx \sqrt{ } 2 a_{T T B}, c \approx 2 c_{T T B}, \mathrm{BN} \quad \mathrm{N}$ is incommensurate and $\mathrm{BS} \mathrm{N}$ has a commensurate cell with $\mathrm{a} \approx$ $\sqrt{ } 2 a_{T T B}, b \approx 3 \sqrt{ } 2 a_{T T B}, c \approx 2 c_{T T B}$ cell. Indexing is in the prototype TTB cell.
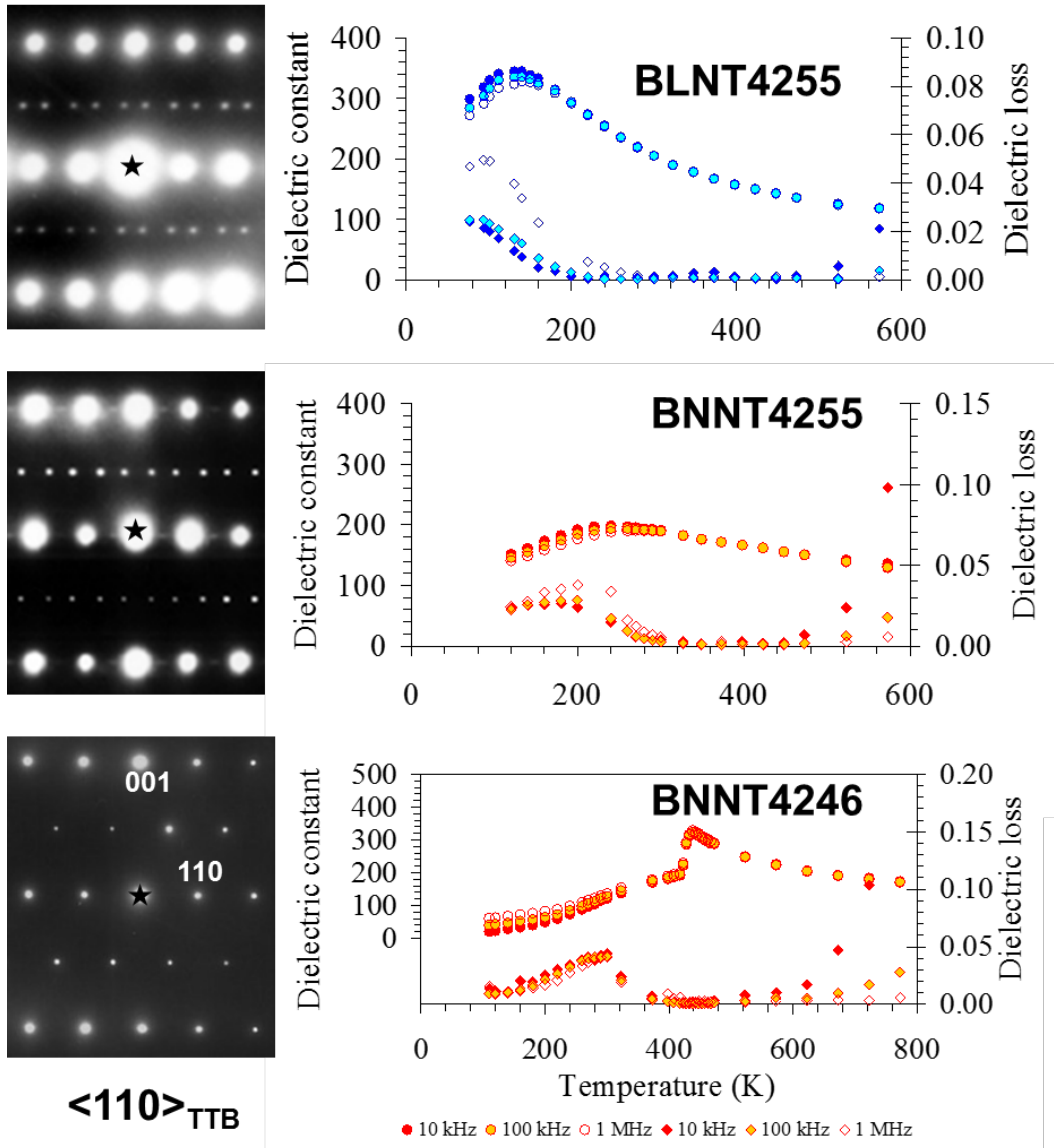

Figure 12. $\left\langle 110>_{T T B}\right.$ zone axis diffraction patterns and dielectric data as a function of temperature for $\mathrm{Ba}_{4} \mathrm{La}_{2} \mathrm{Nb}_{5} \mathrm{Ti}_{5} \mathrm{O}_{29}$ (BLNT4255), $\mathrm{Ba}_{4} \mathrm{Nd}_{2} \mathrm{Nb}_{5} \mathrm{Ti}_{5} \mathrm{O}_{29}$

(BNNT4255) and $\mathrm{Ba}_{4} \mathrm{Nd}_{2} \mathrm{Nb}_{4} \mathrm{Ti}_{6} \mathrm{O}_{30}(\mathrm{BNNT} 4246)$. 


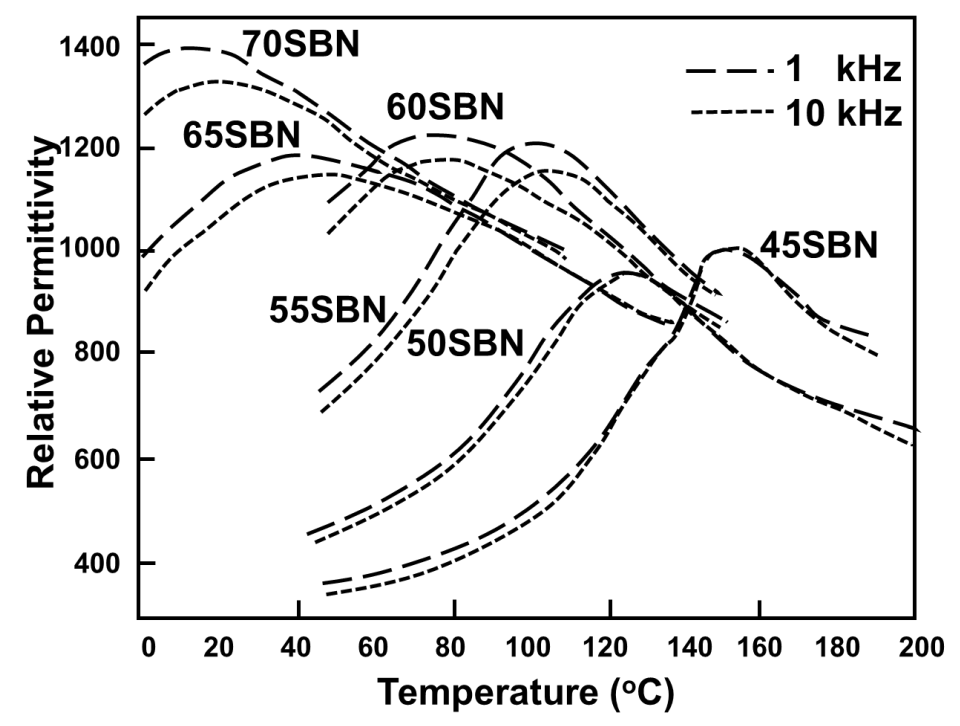

Figure 13. Temperature dependence of relative permittivity as a function of $x$ for $\left(\mathrm{Sr}_{1-\mathrm{x}} \mathrm{Ba}_{\mathrm{x}}\right)_{5} \mathrm{Nb}_{10} \mathrm{O}_{30}$ ceramics. The transition starts to show a frequency dispersion at $x \approx 0.5$, after Kang and Joo. ${ }^{33}$

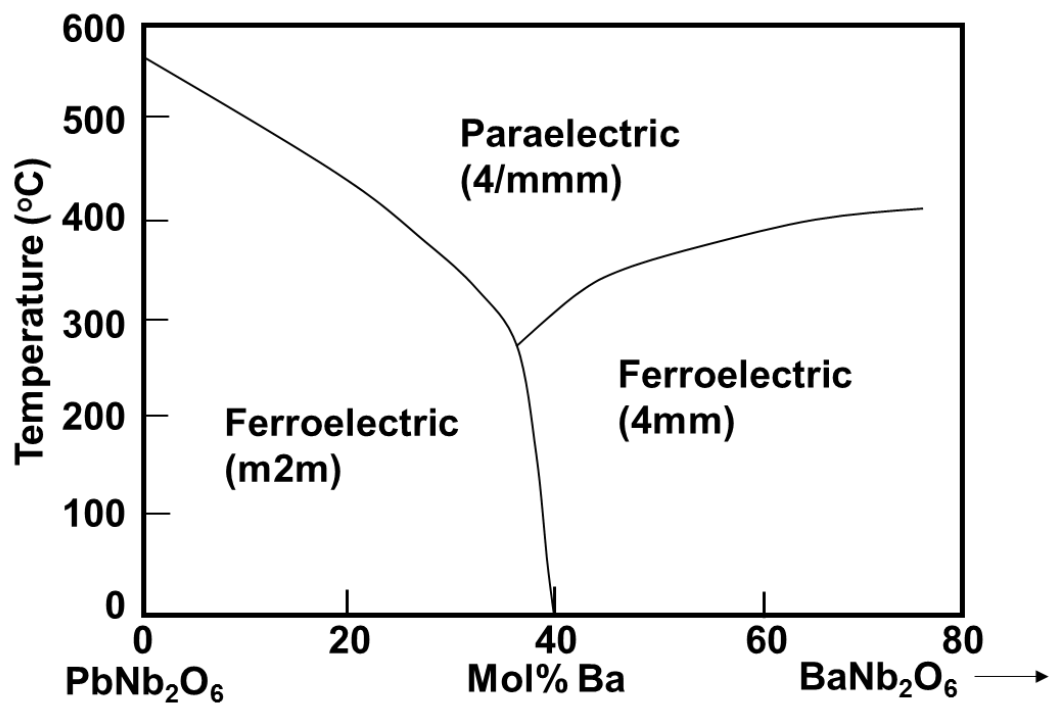

Figure 14. $\left(\mathrm{Pb}_{1-\mathrm{x}} \mathrm{Ba}_{\mathrm{x}}\right)_{5} \mathrm{Nb}_{10} \mathrm{O}_{30}$ phase diagram, after Subbarao et al. ${ }^{9}$ 

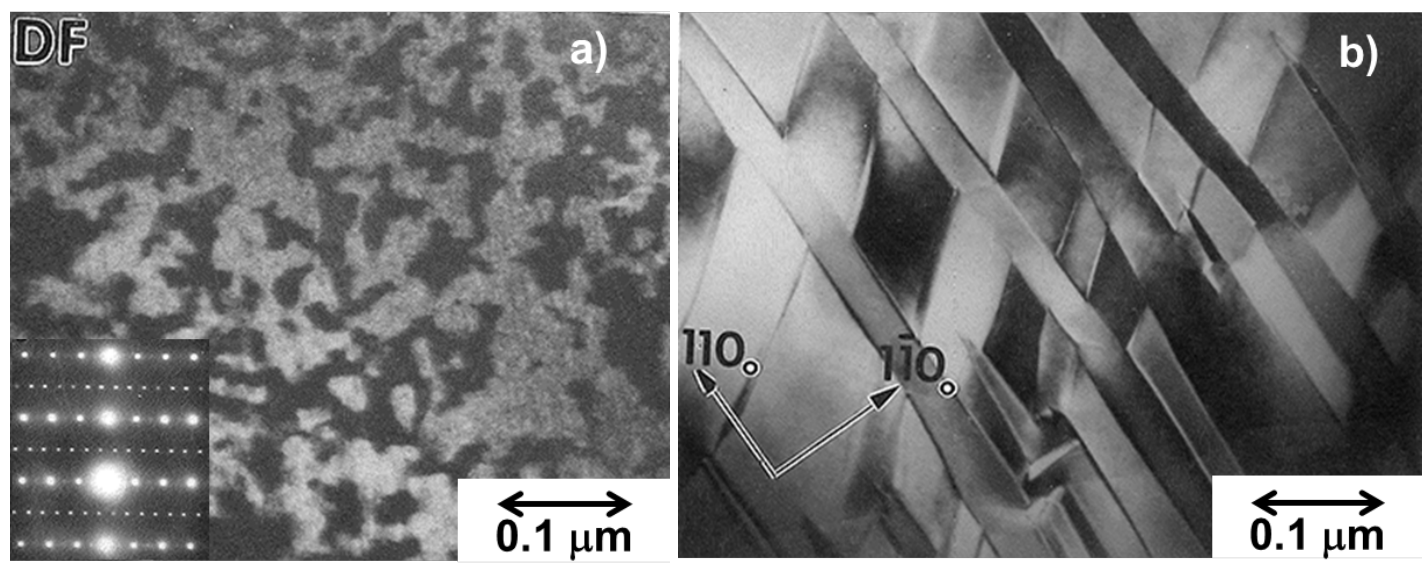

Figure 15a) Discommensurate superstructure regions in $\left(\mathrm{Pb}_{1-\mathrm{x}} \mathrm{Ba}_{\mathrm{x}}\right) \mathrm{Nb}_{10} \mathrm{O}_{30}, x=0.61$ with inset $\langle 110\rangle_{T T B}$ zone axis diffraction pattern showing the incommensurate superstructure reflections for $x=0.25$. b) Bright field TEM image showing $90^{\circ}$ and $180^{\circ}$ domains in $x=0.35$, after Randall et al. ${ }^{12}$

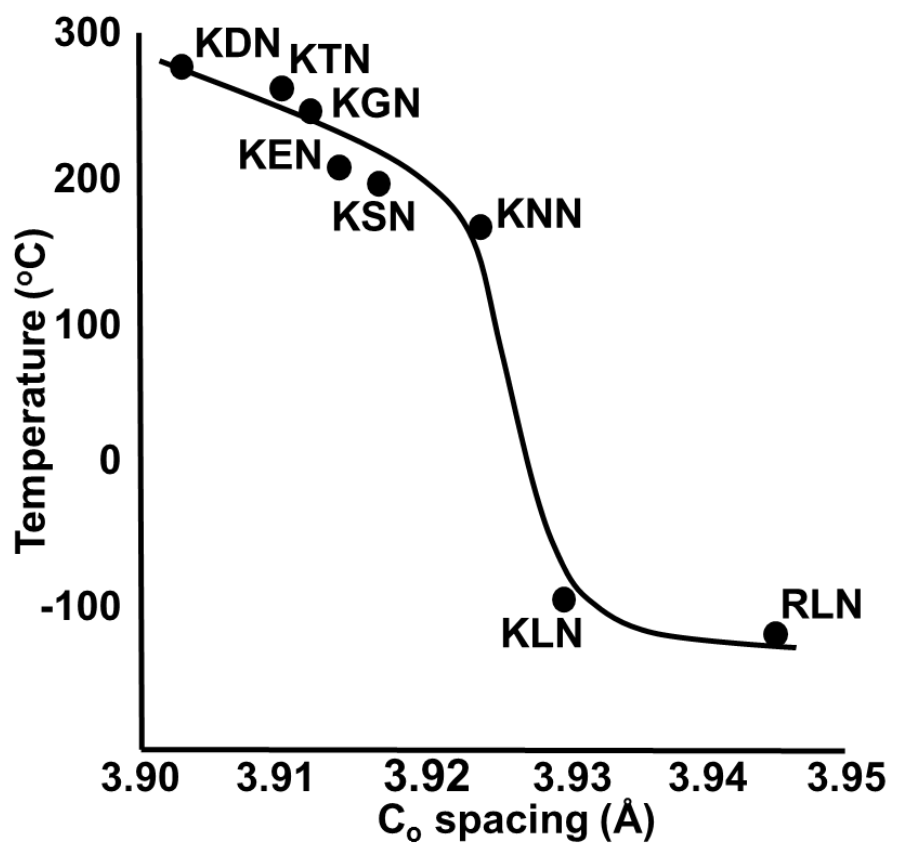

Figure 16. $\mathrm{c}_{0}$-spacing vs temperature of dielectric anomaly for $\mathrm{K}_{4} \mathrm{RE}_{2} \mathrm{Nb}_{10} \mathrm{O}_{30}(\mathrm{KREN}, \mathrm{Re}=$ La, Nd, Sm, Eu, Tb, Dy) and $\mathrm{Rb}_{4} \mathrm{La}_{2} \mathrm{Nb}_{10} \mathrm{O}_{30}(\mathrm{RLN})$, after Scott et al. ${ }^{44}$ 


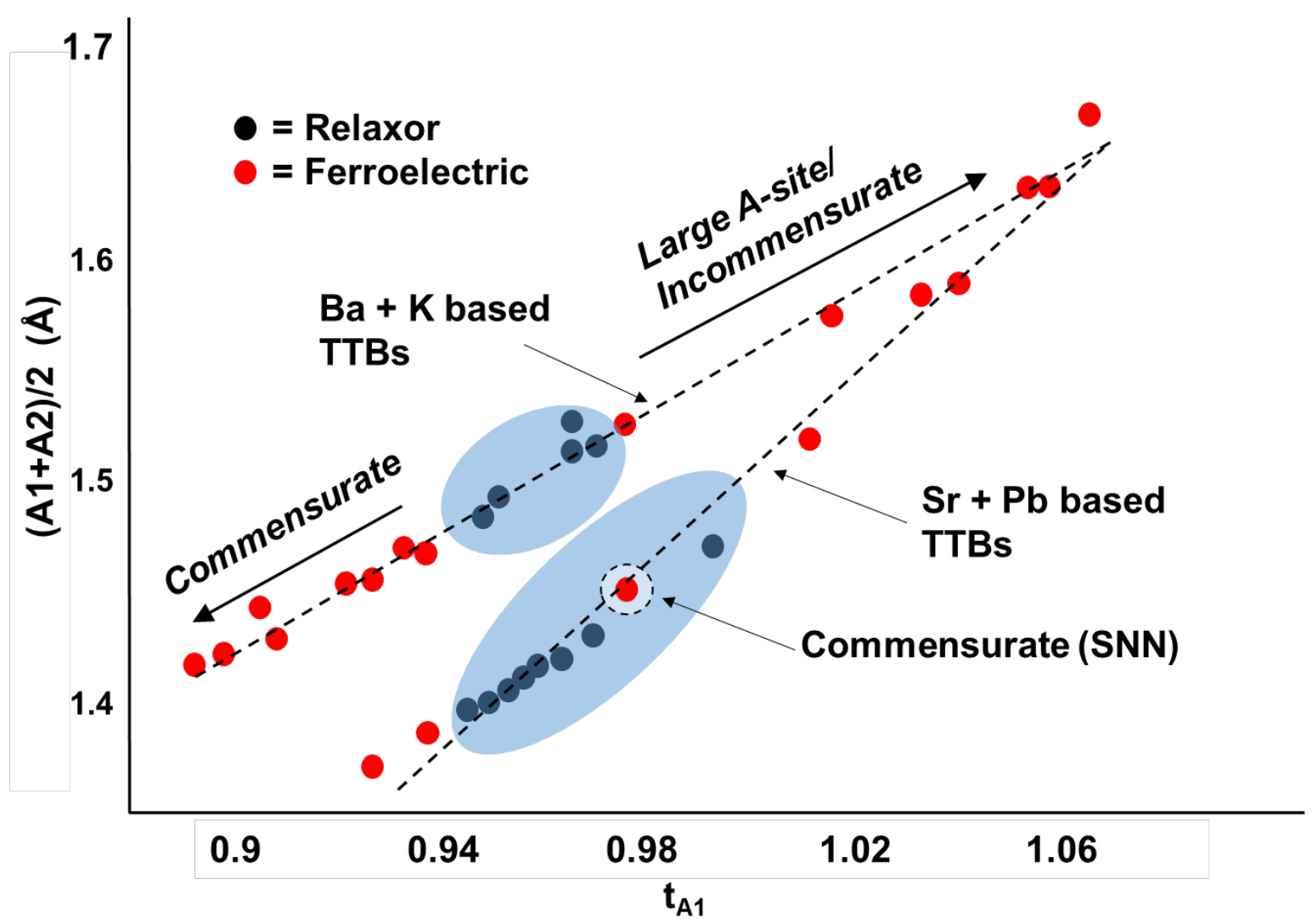

Figure 17. Average A-site size $(A 1+A 2) / 2)$ vs A1 tolerance factor $\left(t_{A l}\right)$ for the TTB structured compounds in Table 2. A large average $(A 1+A 2) / 2$ stretches the $B$-O bond length and enhances $d^{0}$ polarisability, resulting in long range ferroelectric order. The $A 1$ tolerance factor (perovskite sites) is related to the driving force for the onset of commensurate tilting which also promotes ferroelectricity. In between, relaxor behavior dominates. Two trend lines arise because $\mathrm{Ba}^{2+} / \mathrm{K}^{+}$and $\mathrm{Sr}^{2+} / \mathrm{Pb}^{2+}$ have similar ionic radii (Table 2). $\mathrm{Sr}_{4} \mathrm{Na}_{2} \mathrm{Nb}_{10} \mathrm{O}_{30}$ (SNN) is ferroelectric ${ }^{39}$ but lies in the relaxor phase field. However, this compound is commensurate with $\operatorname{Im} 2 a$ symmetry $\left(a \approx 2 \sqrt{2} a_{T T B}, b \approx 2 \sqrt{ } 2 a_{T T B} \text { and } c \approx 2 c_{T T B}\right)^{40}$ and therefore according to our framework should be ferroelectric. 